\title{
ANACARDIACEAE: Rhoideae: Astronium
}

Fred A. Barkley *

The genus Astronium had its historical origin with the publication of Astronium graveolens in 1760 by Jacquin, who in 1763 published a drawing of the fruit, and in $1780 \mathrm{a}$ drawing of the fruit and a leaf. The original specimens were cited as having come from Jamaina** and Colombia. In 1827 Schott published two additional species, Astronium fraxinifolium very similar to the original species, and Astronium concinnum, an extremely distinctive species.

In 1862 Manoel Freire Allemäo (in Francisco Freire Allemão \& Manoel Freire Allemão) published the genus Mvracrodruon based on the species M. urundeuva, this genus being separated by having spherical ovaries in fruit as contrasted to the fusiform ovaries in the fmits of Astronium. Grisebach in 1864 published the species Astronium oblicuum from Trinidad.

Engler originally, in the work of Martius and Eichler of 1876, kept Myracrodruon separate from Astronium, transferring A. concinnum and describing $\mathrm{M}$. macrocalyx, both having the ovary in fruit obconical in form (and by the present writer considered synonymous). However,

* Department of Biology, Northeastern University, Boston, Mass.

Two grants from the American Philosophical Society made the study possible. The writer is also grateful to the many curators from which specimens were borrowed for this study; and especially, so to the directors, and curators del Herbario del Instituto de la Botánica de 12 Fundación Miguel Lillo de la Universidad de Mucuman (Argentina) where the study was started, the Herbarium of the Chicago Natural History Musoum, the Herbarium of the Ner York Botanical Garden and the Herbaria of Harvard Iniversity, where the study has been continued.

The original illustrations prepared by the artists of the Fundación Miguel Lillo and the accompanving manuscript, which had been submitted for publication to the Proceedings of the Iraqi Scientific Societies, nermanently disappeared during the 14th of Ramadan Revolution, thereby much delyying the publication of this study.

* The present writer has seen no material of the genus from the West Indies, except from Trinidad. 


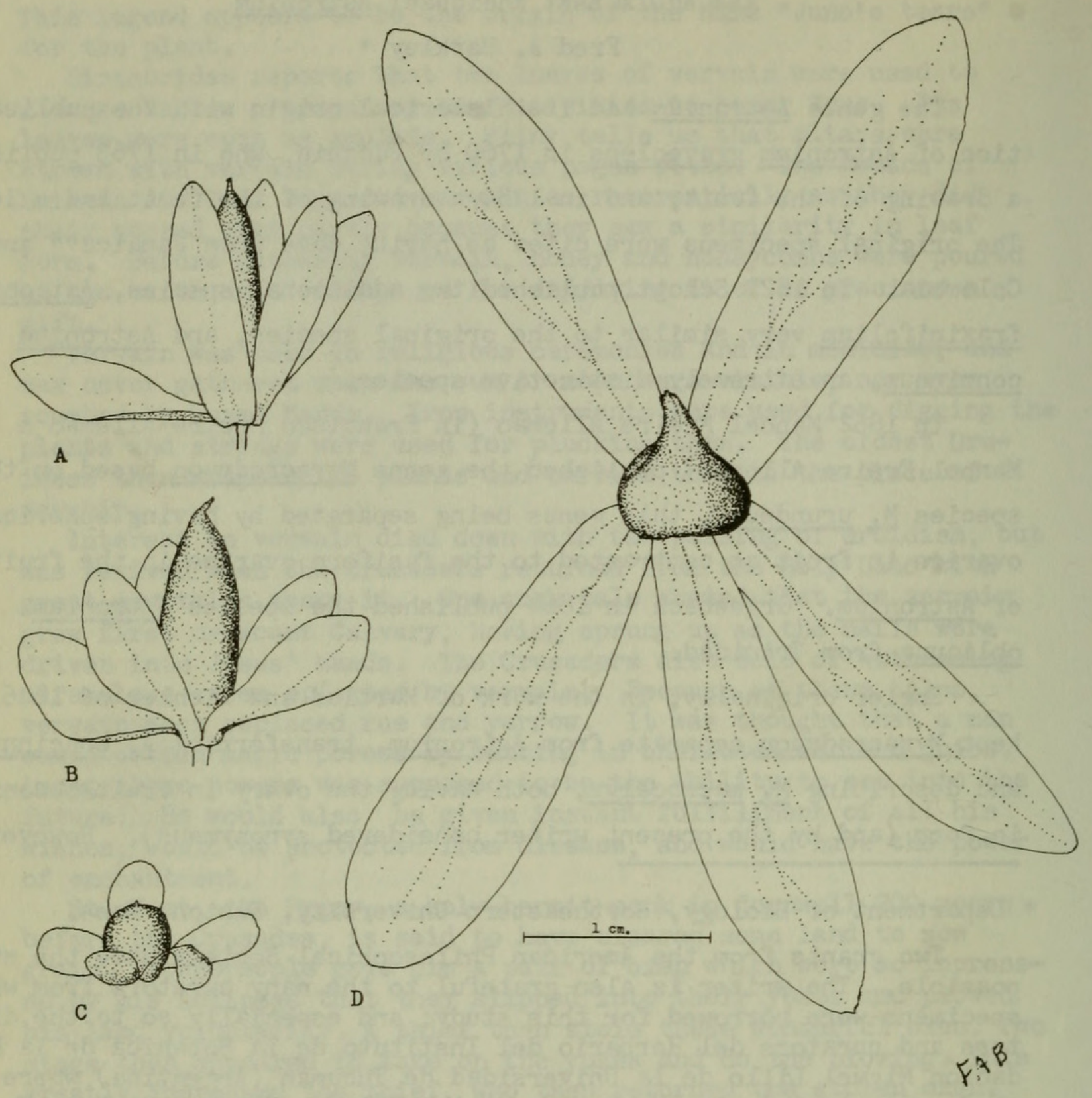

PLATE I. Fruit of Astronium. A. Astronium fraxinifolium Schott from Gardner 1535 of 1839. B. Astronium gracile var. acuminatum (Chodat \& Hassler) Barkley from Hassler 6224. C. Astronium urundeuva (Fr. Allamão) Engler from Venturi 5043. D. Astronium concinnum Schott from Glaziou 15903. 
in 1881 he described another species, Astronium balansae, having the ovary spherical in fruit, and submerged Myracrodruon in Astronium as a section.

This treatment of Engler was followed without change except for the publication of Astronium conzatii Blake in 1918 and $\mathrm{A}_{0}$ lecointei Ducke in 1922, until the publication of a monograph by Mattick in 1934 in which three additional species were described, A. ulei, 杰 gardneri, and A. glaziovii, and several forms were named.

In common with many genera of the tribe Rhoideae the members of this genus have cyclic, heterochlamydic and 5-parted flowers, with a superior, tricarpellary compound pistil but with a single fertile carpel which contains a single apically attached ovile. The stamens are 5 and alternate with the petals. There is a disk between the stamens and pistil (fig. 1 ). In the staminate flowers the sepals are usually orbicular, but in the pistillate flowers are obovate and grow very rapidly after pollination, usually the growth in their length about equalling the growth of the ovary in those having obconical or spherical ovaries in fruit. The five enlarged persistent, sepals are

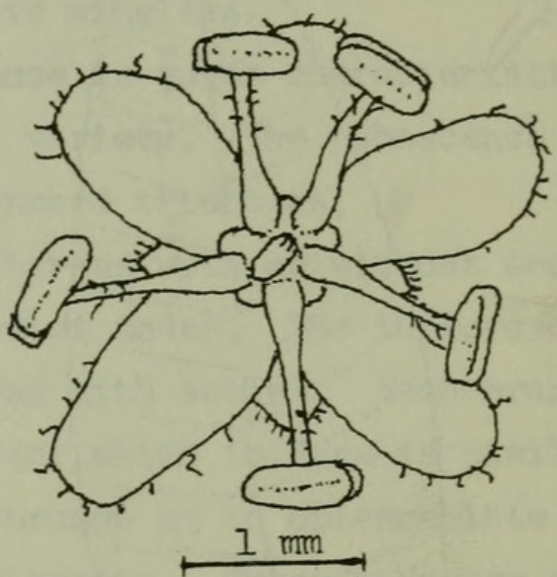

Figure 1. Staminate flower of Astronium urundeuva (Fr. All.) Engler, from Hassler 11890. characteristic of the fruits. The petals do not increase in size in fruit, but are persistent.

The fruit of all species has a thin exocarp and resinous mesocarp. The fruit in $A_{0}$ concinnum has comparativelv enormous sepals, the ovary is obconical and slightly five-lobed at the base, and has a very thin endocarp on the somewhat flattened seed; $\underline{A}$. bal. ansae and A. urundeuva have spherical ovaries, thick, bony, and very rough 


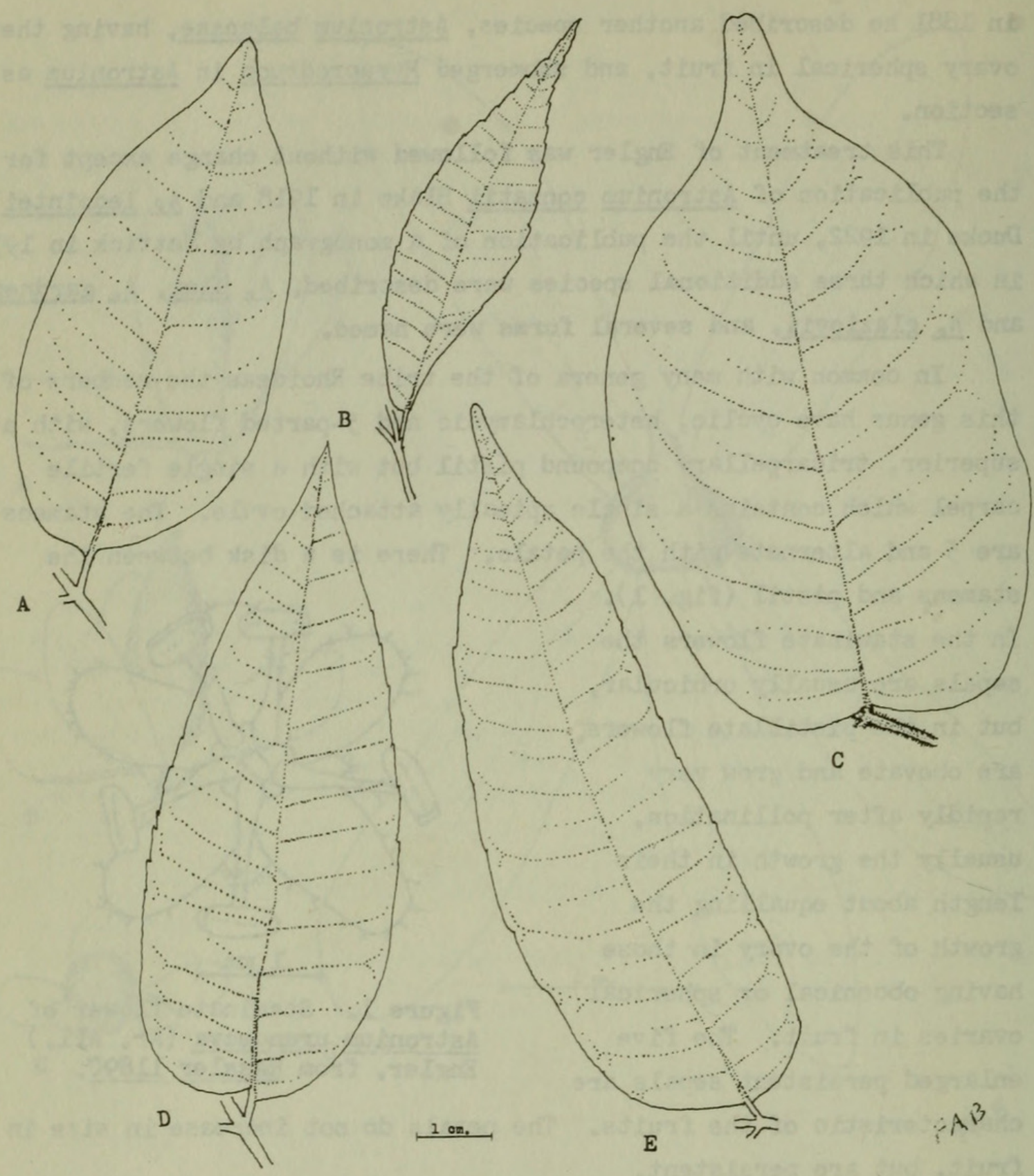

PLATE II. Leaflets of Astronium. A. Astronium concinnum Schott from Glaziou 15903. B. Astronium balansae Engler from Lillo 10587. C. Astronium fraxinifolium Schott from Pittier 8679 . D. Astronium urundeuva (Fr. Allamão) Engler from Hassler 11890. E. Astronium graveolens Jacquin from Curran 354. 
endocarp, and more or less spherical seeds; the other species all have long fusiform fruits, thin and more or less smooth endocarn, and long fusiform seed.

The species are apparently forest trees of considerable size, but information in regard to size and shape of tree and trre of root system is remarkably scanty.

Schizo-lysigenous canal.s are present in the phloem and extend tc the leaves and flowers. The contents of these canals apparently is non-toxic.

The leaves are always alternate and imparipinnately (or very rarely an occasiona? leaf paripinnately) comnound, and usuelly short petjolu'ate. The laminae are usvally thin. The unper surface may be lustrous or dull. The laminae entire or finely serrate and are rarely slightly revolute. The rachis is wingless.

With a few exceptions the pubescence is quite characteristic in abundance and size for each species or variety. The pubescence when present is characteristically of unbranched trichomes.

The inflorescence is a terminal thyrsus with or without accompanving panicles produced in the uppermost nodes. The inflorescences are produced in distinctive buds covered with scales. Each branch of the inflorescence is subtended by a bract which in form is similar to the scales of the bud, each secondary branch by an oblanceolate bract, and the pedicels by deltoid-lanceolate bracts. These buds are almost as characteristic of the genus as are the enlarging sepals of the pistillate flowers.

The plants being polygamodioecious, either have only pistillate or only staminate flowers. The staminate flowers have small orbicular sepals, well developed stamens, and the ovary is extremely mdimentary; the pistillate flowers have obovate large sepals, which grow very rapidly after nollination, becoming the 'wings' of the fruit, small sterile stamens, and the well developed ovary that enlarges very rapidly after pollination. 
The five petals are persistent, but not enlarged, in fruit.

The disk is usually five-lobed and is not particularly prominent.

The stamens are borne under the edge of the disk, the anther is oblong-ovate, the filaments are slender but somewhat thickened below. The stamens in the pistillate flowers are rudimentary.

The three stigmas and styles are separate, the styles being very short, the stigma of the fertile carpel being only slightly larger than the other two. They are persistent in fruit.

Specific delimitation is not particularly difficult between most of the species. Astronium graveolens with its varieties, Astronium fraxinifolium with its variety, and Astronium gracile, while typically are very different in appearance from each other have many individuals which are intermediate and therefore are difficult to delimit.

Taxonomically the difficulties involved in the present study are mostly from the fault of sufficient specimens or of sufficient data accompanying the specimens, from the fact that several species flower or fruit, or even flower and fruit, at times when there are no leaves present. Since it is a very widespread genus, it is probable that the paucity of specimens is due to its being a difficult tree to ascend and because of the lack of leaves at flowering time.

The genus ranges from southern Mexico and Jamaica to Trinidad and Colombia, southward east of the Andes to Bolivia, Argentina, and Paraguay.

ASTRONIUM Jacquin

Jacquin, Enum. Plant. Carib. 10. 1760; Jacquin, Select. Stirp. Americ. Hist. Linn. Syst. Deter. 261. 1763; Jacquin, Select. Stirp. Americ. Hist. 126. 1780; Kunth, Ann. Sc. Nat. 1, 2: 341. 1824; De Candolle, Prodr. Syst. Nat. Regn. Veg. 2: 65 . 1825; Bentham \& Hooker, Gen. Plant. 1: 423. 1862; Marchand, Rev. Anac. 177. 1869; Marchand, Terebinthacées et de Ceux de Leurs Prod. Qui sont Util. en Pharm. 179. 1869; Engler in Martius \& Eichler, $\underline{\mathrm{Fl}}$. Prasil 12 ${ }^{2}:$ 398. 1876; Fngler, Bot. Jahrb. $\underset{\sim}{\pi}: 382$, 
391. 1881; Engler in De Candolle, Monogr. Phaner. 4; 453. 1883;

Engler in Engler \& Prantl, Nat. Pflanzenf. $3^{5}: 172.1892$;

Mattick, Notjzbl. Bot. Gart. Berlin 11: 995. 1934; Cabrera,

Rev. Museu la Plata n.s. 2: 43.1938.

Myracrodruon Man. Fr. Allemão, in Fran. Fr. Allemão \& Man، Fr. Allemão,

Trabal. da Comm. Scient. de Explor.: Secção Botanica $1:$ : 3.1862 ;

Bentham \& Hooker, Gen. Plant. $\underset{\sim}{\sim}$ : 1000. 1867; Engler in Martius

\& Eichler, F]. Brasil 122: 400. 1876.

Deciduous trees with hard wood. Leaves alternate, imparipinnate; laterel leaflets more or less unequal, more or less opposite, shortly potiolulate, the terminal leaflet petiolulate, leaflets entire or finely serrate, glabrous to pilose, acute to acuminate a.t apex, at base obtuse. Flowers polygamodioecious, small. in ample panicles at the uppermost axils and in terminal thyrsi, the inflorescences shorter than the leaves, produced in nerulate buds. Calyx of 5 sepals, these accrescent in the pistillate flowers. Petals 5, oblong or oval, smaller in the pistillate flowers, persistent in fruit, in the staminate flowers about twice as long as the sepals. Stamens 5, alternate with the petals and lobes of the disk, the filaments slender but somewhat enlarged below, the anthers oblong-ovate, in the staminate flowers the stamens usually slightly exceeding the petals, in the pistillate flowers sterile and much smaller. Disk annular, 5-lobed. Ovary 3-carpelled (rarely abnormal and 2-carpelled). Stigmas and styles minute, persistent. Ovary in fruit oblong-fusiform or obovoidfusiform, obconical or spherical, the epicarp thin, the mesocarp resinous, and the endocarp either membranaceous-chartaceous or bony. ovules suspended from the apex of the cavity of the carpel. The seed exalbuminous, the cotyledons plano-convex, elongate, the radical short and straight. Forest trees of the American tropics. 


$$
\stackrel{\mathrm{KEY}}{=} \mathrm{TO} \quad \mathrm{THE} \quad \mathrm{TAXA}
$$

1 Involucrate with calyx lobes (in fruit) slightly longer than the fusiform, apiculate fruit. I. Subgenus EUASTRONIUM

2 Leaflets 3 to ? (mostly 5), all oval, very slightly oblique, glabrous, shining above, subacute.

1. Astronium ulei

2 Leaflets 5 to 25 , lanceolate to rotund, usually noticeably oblique, usually acute to acuminate.

3 Leaflets 17 to $25,1.5$ to $2 \mathrm{~cm}$. long.

3. Astronium glaziouvii

3 Leaflets 5 to 15,3 to $16 \mathrm{~cm}$. long.

4 Leaflets (usually narrowly) ovate-lanceolate or oblonglanceolate.

5 Leaflets entire or essentially so.

6 Leaflets narrowly lanceolate.

5. Astronium gracile

6 Leaflets broadly lanceolate.

7 Leaflets ovate-lanceolate.

4. Astronium obliguum

7 Leaflets oblong-lanceolate.

2. Astronium lecointei

5 Leaflets subentire; serrate or sometimes only indistinctly crenulate.

6 Leaflets narrowly lanceolate or oblong-lanceolate.

7 Leaflets shortly acuminate.

8 Leaflets finely serrate, glabrate or subglabrate, at least at maturity.

5. Astronium gracile

8 Leaflets subserrate.

9 Leaflets glabrous or subglabrous at maturity.

52. Astronium gracile var. acuminata

9 Leaflets velvety pilose at maturity at least below.

8a. Astronium conzattii var. lundellii

7 Leaflets long acuminate, distinctly serrate.

8 Leaflets glabrous or essentially so. 
9 Leaflets thickish, broadly lanceolate, obscurely serrate.

5a. Astronium gracile var. acuminata

9 Leaflets thin, narrowly lanceolate, finely but sharply serrate.

8b. Astronium conzattii var. standleyi

8 Leaflets sparsely pilose.

8. Astronium conzattii

6 Leaflets broadly lanceolate or ovate-lanceolate.

7 Leaflets pilose at least below.

8 Leaflets pilose.

7a. Astronium graveolens var. inodorum

8 Leaflets densely velvety-pilose above and below.

9. Astronium mirandai

7 Leaflets glabrous below.

8 Leaflets broadly ovate-lanceolate, abruptly acuminate.

7b. Astronium graveolens var. dugandii

8 Leaflets oblong-lanceolate, abruptly acutish.

7. Astronium graveolens

4 Leaflets ovate, oblong-ovate, or rotund.

5 Leaflets subentire to distinctly serrate.

6 Leaflets cuneate to broadly cuneate at the base.

7 Leaflets densely velvety-pilose above and below, narrowly ovate.

9. Astronium mirandai

7 Leaflets, if pilose, not densely so.

8 Leaflets, if pilose, not densely so.

7a. Astronium graveolens var. inodorum

8 Leaflets glabrous.

7b. Astronium graveolens var. dugandii

6 Leaflets obtuse to cordate-obtuse at the base.

7 Leaflets and stems pilose.

6. Astronium fraxinifolium

7 Leaflets and stems not pilose.

6a. Astronium fraxinifolium var. glabrum

5 Leaflets entire. 
6 Leaflets small, velvety-pilose, dull above.

10. Astronium gardneri

6 Leaflets large, not velvety-pilose above.

7 Leaflets pilose on the veins.

2a. Astronium lecointei var. tomentosum

7 Leaflets glabrous.

2. Astronium lecointei

1 Involucrate with calyx much longer than the ovoid-globose fruit. II. Subgenus MYRACRODRUON

2 Fruit globose-ovoid, endocarp bony; lobes of the calyx in fruit less than $1 \mathrm{~cm}$. Iong. IIa. Section Eumacrodruon

3 Leaflets lanceolate, long petiolulate, serrate or subserrate. 12. Astronium balansae

3 Leaflets ovate or oblong-ovate, short petiolulate, entire or essentially so.

4 Leaves more or less sparsely pilose.

11. Astronium urundeuva

4 Leaves glabrous. 11a. Astronium urundeuva var. candollei

2 Fruits globose-obconical, endocarp chartaceous; leaflets 3 to 9;

calyx segments in fruit $2 \mathrm{~cm}$. long or longer.

IIb. Section Macrocalyx

13. Astronium concinnum

I. Subgenus EUASTRONIUM (Engler) Barkley, n. stat.

Astronium Jacq., Enum, Plant. Carib. 10. 1760; Engler in Martius \& Eichler, Flora Brasil 12 $: \frac{170}{397 .} \frac{1876 .}{1876}$

Section Euastronium Engler in DC., Monog. Phaner. 4: 453. 1883.

Fruit oblong-fusiform, apiculate, the mesocarp is resinous but very thin, the calyx lobes are about the length of the ovary, the endocarp is thin and chartaceous, and the fruit is fusiform and terete.

This section, with species ranging from Southern Mexico to Northern Argentina, is composed of a series of several very similar species each of which show considerable variation. Unfortunately there are insufficient complete specimens available for all of these species to give the excellent understanding of the species that one would like, and as contrasted to the subgenus MYRACRODRUON. 
1. Astronium ulei Mattick, Berlin Bot. Gart. Notizblatt 11: 996. 1934.

Tree to $40 \mathrm{~m}$. high; branches glabrous, grayish-brown; leaves imparipinnately compound with 3 to 7 leaflets, $10-20 \mathrm{~cm}$. long; leaflets thinly coriaceous, shining above, dull beneath, glabrous, ovate or rarely rotund, rounded-obtuse to subacute at apex, roundedobtuse and frequently noticeably unequal at base, the margin subrevolute and entire, 4 to $9 \mathrm{~cm}$. long, 2 to $6.5 \mathrm{~cm}$. broad, the lateral petiolulate with glabrous petiolules about $5 \mathrm{~mm}$. long, the terminal with petiolules $1 \mathrm{~cm}$. long; rachis segments $2-3 \mathrm{~cm}$. long, glabrous; petiole about $4 \mathrm{~cm}$. long, glabrous; panicles axillary to the uppermost leaves, 6 to $25 \mathrm{~cm}$. long, glabrous; pedicels slender, $2-3 \mathrm{~mm}$. long in flower, in fruit 6 to $10 \mathrm{~mm}$., glabrous; bracts triangularovate, .4-.6 mm. long, glabrous except ciliate on the margin; sepals semicircular in outline, $.8 \mathrm{~mm}$. wide, $.5 \mathrm{~mm}$. long, glabrous except ciliate on the margins; petals glabrous, ovate, narrowly obtuse, $1 \mathrm{~mm}$. wide, $2 \mathrm{~mm}$. long; stamens (in the staminate flowers) with anthers oblong, $1 \mathrm{~mm}$. long, $.2 \mathrm{~mm}$. wide, filaments slender, 1.2 m. long (in the pistillate flowers the stamens much smaller); disk extremely thin, $.5 \mathrm{~mm}$. in diameter, 5-lobed; pistil (in the staminate flowers) rudimentary, or in the pistillate with 3 capitate stigmas, 3 short styles and an elongate ovary; the fruit oblong-cylindric, acute at apex and base, the fruit walls adhering, 10-11 mm. long, $3 \mathrm{~mm}$. in diameter, the petals persistent in fruit but not enlarged, the sepals enlarging, cuneate at base, narrowly obtuse to subacute at apex, $3-4 \mathrm{~mm}$. broad, 9-1.1 cm. long.

Type: Brasil : Río Branco: Feb. 1909, E. Ule 2959 in the herbarium of the Berlin Botanical Garden.

Distribution: Known only from northern Amazonas and adjacent British Guiana and Venezuela.

Common name: "Bauwana".

Specimens examined: VENEZUETA: between El Puente and La Vela de Coro, 2 April 1917, Curran \& Haman 457 (VEN) and La Vela de Coro, 4 April 1917, $496(\mathrm{GH})$; BRITISH GUIANA: western extremity of the Kanuku 
Mountains in the drainage of the Takutu River, $300 \mathrm{~m}$. alt., "tree to $15 \mathrm{~m}$. high, with very few leaves", 4-22 March 1938, Smith 3126 (F, G, $\mathrm{NY}, \mathrm{S}, \mathrm{US})$ and northwestern slopes of the Kanuku Mountains in the drainage of Moku-moku Creek, between $150-400 \mathrm{~m}$. alt., "tree to $40 \mathrm{~m}$. high, petals pale green", 31 Mąrch-16 April 1938, 3466 (F, G, LIL, NY, S, US); BRAZIL: RIO BRANCO: Río Surumu: Serra de Pracana (Pacaraina), Feb. 1909, Ule 2960 (G, MG, NY, US) and March 1909, 1958 (G, MG, NY).

2. Astronium lecointei Ducke, Arch. Jard. Bot. Rio de Janeiro 3: 202. 1922; Mattick, Berlin Bot. Gard. Notizblatt 11: 1006. 1934. Large tree; branches maroonish gray, thickish, glabrous; the leaves $15-35 \mathrm{~cm}$. long, pari- or imparipinnately compound, with about 8 or 9 leaflets; leaflets shining above, completely glabrous, 7 to $15 \mathrm{~cm}$. long, $2-4.5 \mathrm{~cm}$. broad, abruptly long acuminate at apex, more or less unequal and obtuse at base, petiolulate on petiolules $8-12 \mathrm{~mm}$. long; internodes 3.5 to $5 \mathrm{~cm}$. long; petiole 6 to $8 \mathrm{~cm}$. long; inflorescences panicles 8 to $30 \mathrm{~cm}$. long, glabrous, produced in cataphyll covered buds in the axils of the uppermost leaves; staminate flowers pedicellate on glabrous pedicels about $1 \mathrm{~mm}$. long, sepals orbicular, obtuse, $.5 \mathrm{~mm}$. broad, $.5 \mathrm{~mm}$. long, petals oblong, obtuse, $1.2 \mathrm{~mm}$. broad, $2 \mathrm{~mm}$. long, stamens with filaments slender, anthers oblongovate, $1.2 \mathrm{~mm}$. long, $.5 \mathrm{~mm}$. broad, the disk thin; the pistil rudimentary; pistillate flowers similar except sepals oblong-orbicular, 1.2 mm. broad, $1.5 \mathrm{~mm}$. long, the petals slightly smaller and narrowed above, the stamens are rudimentary, and the pistil is about $2 \mathrm{~mm}$. long, with three hemispherical stigmas, and three styles; fruit with calyx lobes about $1.4 \mathrm{~cm}$. long, 3.5 to $4 \mathrm{~mm}$. broad, rounded obtuse to subacute at apex, petals persistent, $2 \mathrm{~mm}$. long, the ovary cylindric, narrowed at apex and base, about $4 \mathrm{~mm}$. in diameter and as long as the sepals.

Type: Brazil: Para: in regione fluminis Trombetas ad orientem lacus Salgado, A. Ducke (13188) in the herbarium of the Jardim Botanico do Río de Janeiro no. 8. Dr. Ducke points out that it is a $\operatorname{tall}$ forest tree and without leaves at the time of flowering. His original description of the species is: "Speciei A. fraxinifolium Schott simile, differt praesertim foliolis adultis superne nitidissimis apice acutissime acuminatis, ligno interiore primum albido demum flavidobrunnescente, fasciis longitudinalibus irregularibus insigniter ornaton. 
To the present writer A. lecointei has its nearest affinity in A. ulei. Steyermark 62871 is somewhat like $A_{0}$ graveolens in appearance.

Distribution: Venezuela and the upper Amazon drainage of Brazil.

Common names: "Misionero", "Miracoatiara", "Muiraquatiara".

Specimens examined: VENEZUELA: BOLIVAR: La Prisión en el medio Río Caura, $120 \mathrm{~m}$. alt., "uno de Ios árboles mas altos que se encuentra en el medio Caura, a menudo alcanza a 40 metros de altura", 30 March 1939, Williams 11655 (F, US, VEN); SUCRE: dry rocky Chaparral near Quetepe, alt. $30 \mathrm{~m} ., 23$ May 1945, Steyermark 62871 (F, LIL);

BRAZIL: PARÁ: Obidos, 27 Sept. 1915, Ducke \& LeCointe 15256 (G, MG) and Oct. 1918, 1256 (G); Obidos, 23 Jan. 1918, Ducke s.n. (MG), 19 Oct. 1919, 11390 (S) and 20 0ct. 1919, 11390 (G, US); ad orientem lacus Salgade prope fluminis Trebetas, "arbor magna, in silvis", 23 Oct. 1919, Ducke 8 (G, S, US); circa cataratąs Mangabal en el Rio Tapajoz, 8 Aug. 1923, Ducke 18162 (S, US), and Río Tapajoz, 13 Aug. 1923, 18161 (G, S, US); AMAZONAS: Manaos: Estrada do Aleixo, i? June 1932, Ducke 24814 (S, US), (fruiting) 14 oct. 1941, 852 (BEI, F, MG, NY, US) and (Flowering) $18 \mathrm{Dec} .1943,852$ (BEL, F, US ); Jose-Assu, 19 Sept.. 1932, Ducke 24816 (s); Codajas: Lago de Bedajos, 26 Aug. 1950, Froes s.n. (BET).

2a. Astronium lecointei var. tomentosum (Matt.) Barkl., n. stat.; Astronium LeCointei f. tomentosum Mattick, Berlin Bot. Gard. Notizblatt 1]: 1007.1934.

Similar to the species but with petiole, petiolules, and veins minutely tomentose-pilose.

Type: Brazil : Para: Belém do Pará, 14 Nov. 1915, A. Ducke 15813 in the Delessert Herbarium at Geneva, Switzerland.

Common name: "Muiracoatiara".

known only from the type collection.

Specimens examined: BRAZII: PARÁ: Belém do Pará, 14 Nov. 1915 , Ducke 15813 (G, US).

3. Astronium glaziovii Mattick, Berlin Bot. Gard. Notizblatt 길: 1007. 1934.

Branches terete, glabrous or at first densely holosericiouspilose; leaves imparipinnate with 14 to 27 leaflets, the petiole angulate or very narrowly margined between the leaflets, at first sparsely pilose, the segments 8 to $15 \mathrm{~mm}$. long; leaflets subsessile to petiolulate on petiolules to $1 \mathrm{~mm}$. long, usually subopposite, 12 


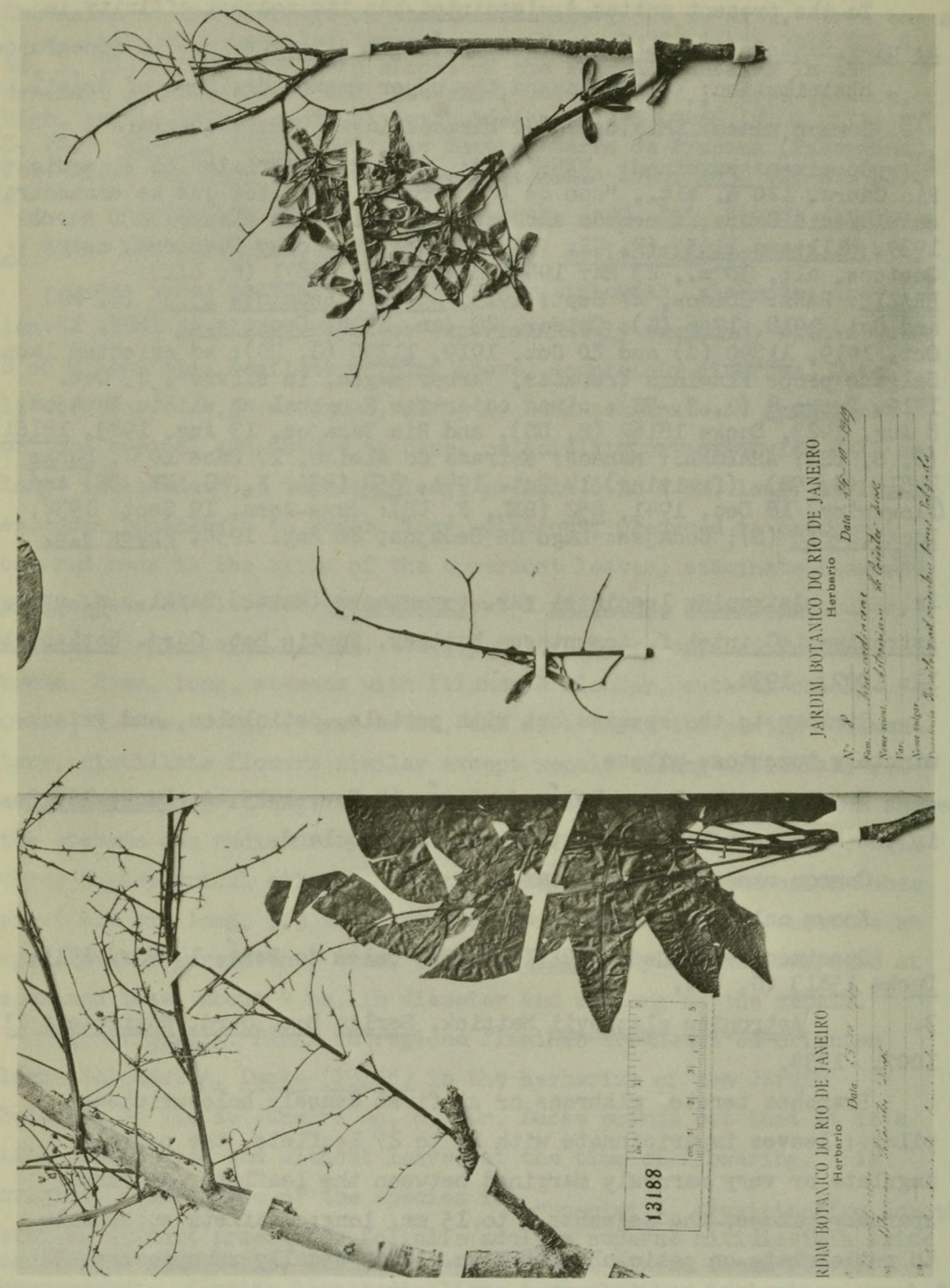

PLATE III. Photograph of Astronium lecointei Ducke from Ducke $\underline{8}$ in the Berlin Herbarium. Note the shape of the fruit. (Photo courtesy of the Field Museum of Natural History, Chicago.) 
to $20 \mathrm{~cm}$. long, .6 to $1 \mathrm{~cm}$. broad, ovate-oblong to rhomboidal, oblique, the halves unequal, the margin crenate-serrate, the veins at least at first sparsely pilose; panicles 10-15 $\mathrm{cm}$. long, narrow, shortly and sparsely pilose; bracts $.5 \mathrm{~mm}$. long, deltoid-lanceolate, acuminate, sparsely pilose, caducous; calyx $1.2 \mathrm{~mm}$. long, ovate, obtuse, glabrous; petals $2 \mathrm{~mm}$. long, glabrous, ovate, obtuse; calyx in fruit ovatelanceolate, obtuse, $1.2 \mathrm{~cm}$. long, 2 to $5 \mathrm{~mm}$. broad; ovary $1 \mathrm{~cm}$. long, 2 um. broad.

The original description of this species (Mattick, Berlin Bot. Gard. Notizblatt II holosericeo-pilosi. Folia impari-pinnata 8-12-juga, 12-15 cm longa, petiolis angulatis vel inter foliola anguste marginatis, pilosis, inter jugis 8-10 m longis. Foliola petiolulis $0,5-1 \mathrm{~mm}$ longis, opposita vel parum alterna, 15-20 mm longa, 6-8 mm lata, ovatooblonga, obliqua latere ad basin folii verso angustiore, margine crenato-serrato, in petiolulo, costa et venis praecipue supra leviter pilosula. Flores masculi desunt. Paniculae fructiferae $12-15 \mathrm{~cm}$ longae et latae, pyramidatae, brevissime pilosae, ramulis patentibus. Calycis fructiferi segmenta quam petala 5-6 ies iongiora retreflexa, $11-13 \mathrm{~mm}$ longa, 4-5 mm lata. Petala oblonga $2 \mathrm{~mm}$ longa, $1 \mathrm{~mm}$ lata. Fructus elongate-oblongus acutatus 9-11 mm longus, 2-2.5 mm crassus."

Type: BRAZIL: MINAS GERAB̈S: Glaziou 19011 in the Royal Botanical Garden Herbarium, Kew.

Distribution: Minas Geraës to Rio de Janeiro, Brazil.

Specimens examined: BRAZII: 29 May 1866, Allemão S.n. (R); MINAS GERAËS: 20 Dec. 1939, Heringer 263 (F, SP); RIO DE JANETRO: Morro dos Cabritos: Lagoa Rodriog de Freitos, 27 Aug. 1939, Kuhlman S.n. (F, RB); Morro de Sacopan: Lagoa Rodriguez de Freitos, 30 Nov. 1939, Kuhlman 6023 (F, RB).

4. Astronium obliquum Friseb., Fl. Brit. W. Ind. 176. 1864; Engler in DC. Monog. Phaner. 4: 453. 1883; Mattick, Berlin Bot. Gard. Notizblatt 11 : 997 . 1934.

Tree of 7 meters; leaves about $20 \mathrm{~cm}$. long, imparipinnately compound, with about 7 to 9 leaflets; leaflets glabrous, ovate lanceolate, 3.5 to $6.5 \mathrm{~cm}$. long, 2 to $3 \mathrm{~cm}$. broad, acuminate or subacuminate at apex, cuneate and (in the case of the lateral leaflets) very unequal at base, shortly petiolulate; rachis segments $2-3 \mathrm{~cm}$. long, glabrous; 
petiole glabrous, $4-5 \mathrm{~cm}$. long; sepals orbicular, about $1 \mathrm{~mm}$. in diameter, glabrous or in fruit about $1.2 \mathrm{~cm}$. long; petals obovate, 1.5-2 m. long, $1 \mathrm{~mm}$. broad.

Type: Trinidad: in silvis montiem septentrionatum Crueger 289 from the Grisebach Herbarium in the Herbarium of the Berlin Botanical Garden.

This species, apparently very distinctive, but related to $\underline{A}_{\text {}}$ graveolens, is limited in distribution to the island of Trinidad. Good fruiting material nor good staminate flowering material have not been available for my study.

Common name: "Yoke".

Specimens examined: TRINIDAD: Scotland Bay, tree of 7 meters, on coastal hillside, 12 April 1920, Britton \& Hazen 1706 (GH, NY, US); Botanic Gardens, ? March 1925, Broadway 5577 (GH, S).

5. Astronium gracile Engler, Bot. Jahrb. 1: 45.1881.

Astronium gracile f. serratum Mattick, Berlin Bot. Gard. Notizblatt 11: 999.1934.

Tree; branches coarse, glabrous; leaves thin, imparipinnately compound with about 13 leaflets; leaflets glabrous, thin, oblonglanceolate to oblong-ovate, 1.5 to $4 \mathrm{~cm}$. broad, 4.5 to $9 \mathrm{~cm}$. long, abruptly acute, subserrate to serrate, broadly cuneate to subcordate at base, petiolule 3 to $4 \mathrm{~mm}$. long; inflorescence a terminal thyrsus and panicles at the uppermost nodes; sepals rotund, obtuse, glabrous, $1 \mathrm{~m}$. long; petals ovate, obtuse, glabrous, $2 \mathrm{~mm}$. long; anthers oval, $1 \mathrm{~mm}$. long; filaments slender, $1.5 \mathrm{~mm}$. long; sepals in fruit oblanceolate, $1.2 \mathrm{~mm}$. long, $4 \mathrm{~mm}$. broad, rounded at the apex, ovary in fruit fusiform, $1.2 \mathrm{~mm}$. long, $4 \mathrm{~mm}$. broad.

Type: Engler originally cited two specimens from the De Candolle Herbarium in Geneva: Balansa 2527 and Casarette 552. The present writer having studied (presumably all of) the specimens from the Institut de Botanique Systématique de I'Université de Genèva saw neither of these specimens. Mattick cited both of the specimens but only from the Berlin Herbarium which has since been destroyed. Ingler 
in 1883 in the De Candolle Monographs cites the above two specimens and additionally Glaziou 2390, also from the De Candolle Herbarium. Mattick cites this from both the De Candolle Herbarium and Berlin, and there are duplicates in at least three other herbaria. There having been no type designated previously the author believes that the specimen best considered typical for the species is: Brazil: Rio de Janeiro: entre Gavea et Tijuca, 10 Agosto 1877 (1879?) Glaziou 2390 in the De Candolle Herbarium of the Institut de Botanique Systématique de I'Université de Genèva.

From the specimens examined the forma serratum of Mattick seems to be within the range of variation of the typical variety. The specimens from Pará and Acre, Brazil, are atypical, the latter may be referable to $A_{0}$ fraxinifolium but are too fragmentary to be certaim. Distribution: Acre, Pará and Minas Geraës, Brazil, to central

Paraguay.

Common names: "Urundej-itá", "Urundé̉-mí", "Urundeih-pará", "Urundeý-pará", "Urundel", "Urundey", "Ubatão", "Ubatan", "Muiracotiara branca", "Gibatão", "Chibatan", "Jeguira".

Specimens examined: BRAZIL: ACRE: Río Yaco, II Aug. 1933, Krukoff 5398 (G, K, UC, US); Río Acre, Sept. 1911, U工e 2551 (K, G); PARA: Tapajez; Boa Vista, 8 Aug. 1932, Capucho 369 (BEL, F, MG), 12 Aug. 1932. 372 (BEL, F), 16 Aug. $\left.1932, \frac{380}{(F}\right)$, and 17 Aug. 1932, Capucho 385 (BEI, F); Obidos, 26 July 1921, Ducke s.n. (MG) 4 Jan. 1916, s.n.

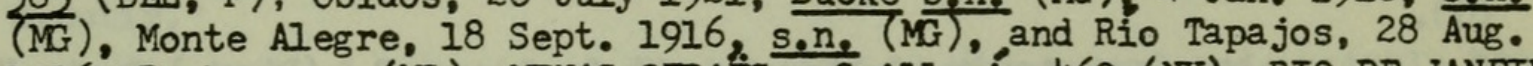
1916, Ducke s.n. (MG); MINAS GRRAES: Guillemin 469 (NY); RIO DE JANEIRO: Aug. 1921, Campos 10519 (LP, US); entre Gavea et Tí juca, 10 Aug. 1877 (1879?), Glaziou 2390 (F, G, R, S, US); Aug. 1921, Occhioni 10519 (S); Sept. 1941, Tatto 18 (US); RIO ACRE: Monte Alegre, Sept. 1911, Ule 2551 (MG); SRO PAULO: Botucatu: Fazenda Lageado, 13 June 1938, Hoehne \& Gehrt S.n. (SP); Amparo: Monte Alegre, 5 April 1943, Kuhleman 5?6 (SP);

PARAGUAY: CONCEPCIÓN: Aug. 1933, Rojas 6182a (BET, LIL); CARAGUATAY: 12 Oct. 1902, Fiebrig 256 (F, G, LP); San Bernardino cerca la Laguna Ypecaraí, 9 Sept. 1916, Osten \& Rojas 2008 (S), 12 Sept. 1916, 2009 (BAF); Oct. 1943, Rojas 10641a (BET, III); Oct. 1943, Pavetti \& Rojas $10641 \mathrm{a}$ (IP); PARAGUARI: Cerro Hu (Thu? ), 7 Sept. 1916, Osten \& Rojas $2010(\mathrm{~S})$.

5a. Astronium gracile var. acuminatum (Chodat \& Hassler) Barkl.

n. stat.; Astronium gracile f. acuminatum Chodat \& Hassler, Bull. Herb. 
Boiss. $1: 6 ? .1903$.

Tree; branches coarse, glabrous; the leaves imparipinnately compound with about 9 leaflets; leaflets thickly membranaceous, usually glabrous but at first sometimes finely pilose on the veins, oblong lanceolate, obscurely but finely serrate, the smaller veins very prominent, acuminate at apex; sepals rotund, obtuse, glabrous, $1.3 \mathrm{~mm}$. long in the staminate flowers; petals ovate, obtuse, glabrous, $2.2 \mathrm{~mm}$. long; fruit with sepals oblanceolate and obtuse, $12 \mathrm{~mm}$. long, $4 \mathrm{~mm}$. broad; the ovary in fruit $1.2 \mathrm{~cm}$. long, $.4 \mathrm{~cm}$. in diameter.

This variety seems to the present writer to be intermediate between A. gracile and A. fraxinifolium var. glabra. Its leaflets are more acuminate, somewhat thicker, and the veinlets are more prominent than that in the typical variety.

Type: Paraguay: "Arbor excelsa 10-25 m. diam. .5-1.2 m. petala flavescentia, in silvis in collibus pr. Tobaty", Sept., Hassler 6224, in the Hassler Herbarium of the Institut de Botanique Systématique de I'Université de Genève (duplicate in the Delessart Herbarium of the same institute).

Known only from the type region.

Specimens examined: PARAGUAY: CARAGUATAY: In regione collium, Cordillera Centralis, Cerros de Tobaty, Sept. 1900, Hassler 6224 (G-TYPE, UC) and 6624 (G); Cordillera de Altos, Aug. 1898, Hassler 3142 (G).

6. Astronium fraxinifolium Schott in Sprengel, (Linn.) Syst. Veg. (VI) $2: 404$. 1827 .

Astronium graveolens var. brasiliensis Engler in Martius \& Eichler, Flora Brasil. $12^{2: 399.1876 . ~}$

Astronium fraxinifolium f. mollissimum Mattick, Berlin Bot. Gard. Notizblatt. 11: 1004.1934.

Tree; the branches pilose or subpilose; leaves imparipinnately compound with 7 to 11 leaflets, the rachis and petiole pilose; leaflets ovate, acute to acuminate at apex, 7-12 cm. long, 3.5-6 cm. broad, entire, pilose on the veins above (sometimes sparsely so), pilose below, densely so on the veins, base subcordate to rounded, shortly petiolulate; 
the inflorescence a terminal thyrsus with or without additional panicles in the axils of the uppermost leaves, the axis sparsely pilose (rarely subglabrous or densely pilose); pedicels $1 \mathrm{~mm}$. long in flower, enlarging to $5-6 \mathrm{~mm}$. in fruit, sparsely pilose; sepals suborbicular, glabrous, about $1 \mathrm{~mm}$. in diameter, or in the pistillate flower longer and growing rapidly; petals obovate, about $1 \mathrm{~mm}$. broad, 1.52 m. long, obtuse, glabrous; stamens with anthers ovate, about I m. long, filaments about $1.5 \mathrm{~mm}$. long; fruit with calyx lobes oblanceolate, rounded subactue, $1.2 \mathrm{~cm}$. long, $3-4 \mathrm{~mm}$. broad, glabrous, petals $1.8 \mathrm{~mm}$. long, obtuse, glabrous, the ovary $1.1 \mathrm{~cm}$. Iong, $2.5 \mathrm{~mm}$. in diameter.

Type: Schott of course did not designate a type and if his specimen exists it has not been eited by Engler nor Mattick. The present writer considers Blanchet 2765 as seen from the Boissier Herbarium of the Institut de Botanique Systématique de I'Université de Genève as typical of the species.

The original description of Henrici Schott in his Fasciculus Plantarum Brasiliensium in Curtio Sprengel's Caroli Linnaei, Systema Vegetabilium (ed. 6) of 1827, p. 404, was: "15. Astronium fraxinifolium Schott. A. foliis pinnatis hirsutiusculis, foliolis $6-8$ jugis lanceolatis acuminatis serratis, paniculis o erectis. In corolla $0^{\prime \prime}$ nectarium 10 lobum, in + staminodia 5 erecta, antheris sterilibus minutis."

The typical variety of the species is widespread and variable both as to shape and size of the leaflets and in pubescence both of leaflet and inflorescence axis; as here interpreted the branchlets below the inflorescence are always pilose.

Common names: "Arantha", "Aroeira", "Aroeira do Campo", "Gonçalo Alves", "Gonzaleiro", "Gonzales do mato", "Guarita", "Quebracho", "Quebrahache", "Sete-carcas".

Distribution: Central Brazil and eastern Bolivia.

Specimens examined: VENEZUETA: CARABOBO: Valencia, 400 to $800 \mathrm{~m}$. alt., 8 Dec. 1919, Pittier 8679 (GH); BRAZII: Etinga sur de Rio St. Francisco, 1838, Blanchet 2765 (G--Isotype of A, fraxinifolium $f$. 
pilosum Matt.); Glaziou S.n. (SU); Río San Antonio, Zehntner 407 (R), and Santa Rita, oct. 1917,369 (R); CEARA: Allemâo s.n. (R); $\frac{23}{23}$ Sept. 1860, Allemăo y Cysneiros 324 (R); Nov. 1838, Gardner 1535 (G, NY, US) and 1839 (GH); PERNAMBUCO: Tapera, 23 June 1933, Pickel 3250 (US); MINAS GERAB̈S: Claussen s.n. (G, NY) and 1878,473 (G); Sierra da Mantiqueira, 22 Sept. 1877 , Glaziou 10490 (R); Ituiutaba, 6 Aug. 1944 , Macedo 439 (SP); Bella Horizonte, 14 Nov. 1939, Mello 10230 (R); MATTO GROSSO: July 1892, Kuntze S.n. (NY); Cuyaba, 3 sept. 1902, Malme 1918a (R, S) and 23 June $1903,1918 \mathrm{~b}$ (S); BOLIVIA: SANTA CRUZ: Sara: Campo del Rấo Ia Perdiz, $450 \mathrm{~m}$. alt., 26 Aug. 19I6, Steinbach $27 \mathrm{~T}$ (III) and bosques en la región Buena Vista, $450 \mathrm{~m}$. alt., 19 Nov. 1924, 6693 (BA, $F, G, I I L, S)$.

6a. Astronium fraxinifolium var. glabrum Engler in DC. Monog.

Phaner. 4: 455. 1883.

Astronium fraxinifolium f. subglabrum Mattick, Berlin Bot. Gart. Notizblatt 11: 1004.1934.

Astronium fraxinifolium f. glaberrimum Mattick, Berlin Bot. Gart. Notizblatt $\underset{71}{\sim}:$ 1005. 1934.

Tree with branches slender, glabrous or subglabrous; leaves imparipinnately compound with about $?$ to 9 leaflets; leaflets ovate, subcordate to rounded at the base, acuminate at apex, glabrous, sparsely pilose on the veins; the inflorescence a terminal thyrsus or with panicles in the axils of the uppermost leaves; pedicels about 2 to $3 \mathrm{~mm}$. Iong, glabrous; sepals orbicular, 1 by $1 \mathrm{~mm}$. , glabrous; petals obovate, glabrous, 1 by 1.5 to $2 \mathrm{~mm}$; stamens with anthers oval, $1 \mathrm{~mm}$. long, filaments somewhat thickened below, $1.5-2 \mathrm{~mm}$. long; fruit with sepals oblanceolate, subacute, $1.1 \mathrm{~cm}$. long, glabrous, the petals in fruit about $1.8 \mathrm{~mm}$. Iong, glabrous, ovary $1.5 \mathrm{~mm}$. thick, $1.1 \mathrm{~cm}$. long.

Type: BRAZIL: RIO DE JANEIRO: Giaziou 12542 (G).

Mattick in his monograph has separated two forms from amongst the glabrous and subglabrous members of this complex. To the present writer there is no reason to separate these forms since they merge into one another. Whether the separation between the typical variety and the present one is justified is a matter of opinion, and even though this variety is connected to the typical variety by some intermediates it seems to me better to separate the two. The problem is complicated by the lack of sufficient collections of staminate, 
pistillate and fruiting materials over a great portion of its range. Until much more adequate collections are available, the exact separation between these varieties and this species with Astronium graveolens must remain a problem, as $A_{\text {f graveolens }}$ var. inodorum is separable from this variety with difficulty in their region of common distribution. A, gracile var. acuminatum is intermediate between this variety and typical A, gracile.

On his specimen of 1899 from Colombia, H. H. Smith says: "The leaves collected in January, the flowers from the same tree in February the 16th.; this is a common tree of the dry forest below $1200 \mathrm{ft} . ;$ grows to 40 and 50 feet, the leaves nearly always have 5 to 7 leaflets".

Common names: "Alemandro macho", "Cuchi-blanco", "Gonçeleiro branco", "Quebracho", "Urunday", "Urundei-pará".

Distribution: From Colombia to Central Brazil, Eastern Bolivia and Paraguay.

Specimens cited: COLOMBIA: ATLANTICO: Casacoima: 150-180 m. alt., "tree of 18-20 meters taI1,.....leaves aromatic", 9 June 1936, Dugand 1041 (COL, F); MAGDALENA: Molino, $250 \mathrm{~m}$. alt., 29 Mar. 1944, Haught 4032 (COI); Santa Marta, "tree to $40 \mathrm{ft}$., common in dry forest below $1000 \mathrm{ft}, . . .$. the buds are dark purple", 1898-1899, Smith 208 (COL, F, NY), Santa Marta, Sept. 1898, 823 (NY), road to Agua Dulce, $50 \mathrm{~m}$. alt., 16 Jan. 1899, 210 (GH, NY), and Santa Marta, 50 m. alt., Feb. 1901, 210 (COL, F, G, S--Isotypes of A. fraxinifolium, f. glaberrimum Matt. ); CUNDINAMARCA: Tocoima, 16 July 1934, Pérez s.n. (COL); BRAZIL: CEARÁ: Baturite, 30 Aug. 1908, Ducke S.n. (MG); MINAS GERAES: entre Sitie and Barbacena, 4 Aug. 1879, Glaziou 12942 (F); Bello Horizonte, Fazed da Cachoeira, 11 July 1935, Mello 1543 (R); RIO DE JANEIRO: Ponta Vegea, 6 Sept. 1931, Brade 11068 (F, R); 1882, Glaziou 12542 (G--Type of A. fraxinifolium var. glabra Fingler and isotype of $A_{0}$ fraxinifolium $f$ subglabrum Matt.); MATTO GROSSO: Cuyaba, 3 sept. 1902, Malme 1918 (S); BOIIVIA: EL BENI: Trinidad: Misiones Guarayes, $250 \mathrm{~m}$. alt., Sept. $\overline{1926}$, Werdermann 2488 (S); SANTA CRUZ: Buena Vista, 450 m. alt., Aug. 1915, Steinbach 1570 (GH, LII, NY); Sara: bosque del Río Surutu, $450 \mathrm{~m}$. alt., 21 Oct. 1917, Steinbach 2532 (G. LII, NY, US); PARAGUAY: Cañadon Platanillos de, Chaco Paraguay, Aug.

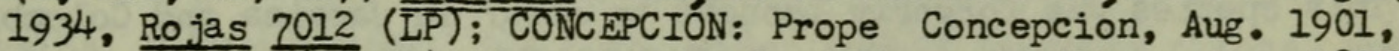
Hassler 7151 (G, UC); CARAGUATAY: Cordillera de Altos, Aug. 1895, Hassler 867 (G), Cordillera de Altos, Aug., 3142 (G, UC) and Monte Cieve-cua prope San Bernardino, Aug., Hassler 1898 (G) and 1898a (G); 
San Bernardino, 12 Sept. 1916, Osten 2009 (III); PARAGUARI: Prope Sapucay, Oct. 1913, Hassler 11898 (G, US) and 11898a (F, G, UC, US). 7. Astronium graveolens Jacq., Select. Stirp. Amer. Hist. Linn. Syst. Deter. 261. 1763; De Candolle, Prodr. syst. nat. reg. veg. 2: 65. 1825; Engler in DC. Monogr. Phaner. 4: 454. 1883; Mattick, Berlin Bot. Gart. Notizblatt 11: 999. 1934.

Tree; branches grayish brown, glabrous; leaves imparipinnately compound with about 11 leaflets, about $20 \mathrm{~cm}$. long; leaflets oblong or oblong-ovate, $2-3 \mathrm{~cm}$. wide, 5-6 cm. long, abruptly subacute, obscurely crenate-serrate, the terminal subcuneate, the lateral obtuse and markedly assymetrical at the base, glabrous; petiolules 5 mm. long in the basal leaflets, progressively shorter above, except terminal about $8 \mathrm{~mm}$. long, glabrous; rachis segments $22.5 \mathrm{~cm}$. long; petiole about $4.5 \mathrm{~cm}$. long, glabrous; inflorescences produced at the ultimate modes of the branches, the flower buds covered with caducous, brown, glabrous cataphylls 2-3 mm. long, one subtending each of the main branches of the panicle; pedicels glabrous, 1-2 mm. long; subtended by caducous, deltoid bracts; sepals glabrous, rounded obtuse, $1 \mathrm{~mm}$. long, sometimes slightly narrower; petals $2.5 \mathrm{~cm}$. long, $1.2 \mathrm{~cm}$. wide, oblong, rounded-obtuse; filaments slender, $2 \mathrm{~mm}$. long, anthers oblong, $1.2 \mathrm{~mm}$. long, $.5 \mathrm{~mm}$. broad; disk thin, shallowly five-lobed, $1.3 \mathrm{~mm}$. in idameter; pistil rudimentary; or in the pistillate flowers the sepals enlarging rapidly, and the pistil large, stigmas hemispherical, styles 3, very short; fruit oblong-cylindric, $1.3 \mathrm{~cm}$. long, acute at apex and base, petals persistent but not enlarging in fruit, the sepals enlarging in fruit, glabrous, lanceolate, rounded obtuse at apex, narrowed at base, $1.3 \mathrm{~cm}$. long, $4 \mathrm{~mm}$. wide.

Type: In regni Novo-Granatensis silvaticis ad Cartagena et Santa Martha, Bertero 2638.

This species was formeriy thought to occur in Jamaica and Colombia, but the writer feels this original citation for Jamaica may have been in error. The type of the species is from Colombia and the species continues with individuals having somewhat smaller leaflets northward 
to southern Mexico. Several variants occur which seem sorthy of varietal rank.

Common names: "Copaiva", "Diomate", "Gateado", "Gonçalo Alves", "Gonzaleiro", "Guzanero", "Palo de Cera", "Palo de Culebra", "Palo de Gateado", "Palomulato", "Palo Obrero", "Quebracho", "Quebrahacha", "Ronrón", "Tibigaro", "Yomate", "Zarro", "Zorro".

Distribution: Southern Mexico to Venezuela and Peru, but the specimens from Central America and Mexico vary toward the appearance of Astronium conzattii.

Specimens examined: MEXICO: YUCATAN: Gaumer 582 (F, G, NY, UPS, US), Izamal, 1895, 584 (F, US), 1917-1921, 24170 (F, G, US) and 19171921, Gaumer 24171 (G); April 1917. Gaumer \& Sons 23722 (F, G, US); CENTRA AMERICA: GUATEMALA: Peten: La Libertad and vicinity, 13 May 1934, Aguilar 227 (F, GH, MICH); EL SALVADOR: La Union: road near La Unión, $15 \mathrm{Feb}$. 1946, Carlson 664 (F, UC); San Marcos: Lempa, 1924, Calderón 2153 (US); Sensonate: San Julian, "furnishes good wood", 1924, Calderon 2216 (NY, GH, US); BRITISH HONDURAS: Crique Negra, 24 May 1929, Stevenson 102 (F) and $27 \mathrm{Mar} .1929,107$ (F); HONDURAS: Yoro: Progreso, $30 \mathrm{~m}$ alt., "tree of $25 \mathrm{ft."}, 24 \mathrm{Jan} .1928$, Standley 25063 (F, GH, US); PANAMA: Panama: around Alha juela, $30-100 \mathrm{~m}$ alt., 25 May 1911, Pittier. 2730 (US); COLOMBIA: 1760-1808, Mutis 4431 (US); ATLANTICO: Megua, $20 \mathrm{kms}$. de Barrānquilla, April 1935, Elias 1305 (F, G, US); BOLIVAR: Loba: Estrella, Caño Papayal, 1916, Curran 354 (F, GH); BOYACA: $1150 \mathrm{~m}$. alt., 1932, Guevara 380 (US); CAUCA: El Tambo, 1800 m. alt., 6 Dec. 1936, von Sneidern 1262 (F, GH); VENEZUELA: GUARICO: on plaza at $\mathrm{ml}$ Sombrero, "tree, leafless at anthesis; flowers yellowish green", $19 \mathrm{Feb}$. 1924, Pittier 11435 (GH, NY, US); PORTUGUESA: Agua Blanco, 24 April 1948, Turner 138 (F); PERU: SAN MARTIN: Zepelacio,

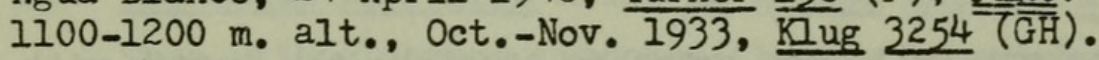

7a. Astronium graveolens var. inodorum Triana \& Planchon, Ann.

Soc. Nat. V, 14:288. 1872.

Astronium graveolens var. Planchonianum Engler in Martius \& Eichler, Flora Brasil $122^{2}: 399.1876$.

Tree, the branches pilose or sparsely pilose; leaves compound with ? (5 to 9) leaflets; leaflets ovate, obscurely serrate, abruptly acuminate, rounded obtuse at base, sparsely pilose except pilose on veins, 7-10 cm. long, $3-4.5 \mathrm{~cm}$. wide; rachis segments pilose, about 3 $\mathrm{cm}$. long; petiole pilose, about $4 \mathrm{~cm}$. long; panicles produced from scale covered buds at the uppermost nodes, glabrous, $2-18 \mathrm{~cm}$. Iong. 
Type: Vallés de Magdalena (Colombia), Triana.

This variety, itself variable, lies between what the present writer interprets at the typical variety and Astronium fraxinifolium.

Triana \& Planchon say the variety is odorless. Dugand describes one of his collections as follows: "tree 10-18 m. high, with a cylindrical, almost straight trunk not exceeding but of ten $50 \mathrm{~cm}$. in diam. It is at once recognized by the bark, of a dark-gray color showing abundant patches of a buffy-gray color; the crown is usually elongated and the leaves aromatic".

Common names: "Diomate", "Gateado", "Quebracha", "Quebra Hacha".

Distribution: Venezuela and the Valley of the Magdalena River of Colombia.

Specimens examined: COLOMBIA: TOLIMA: Mariquita, 300-1200 m. alt., 1851-1857, Triana s.n. (US); ATIANTICO: Puerto Colombia, "desprovisto de hojas durante la inflorescencia". Jan. 1937, milas 15041 (F); road from Malambo to Sabanag rande, "small tree 6-7 meters high", 3 July 1932, Dugand 1059 (F); BOLIVAR: Cartagena, $30 \mathrm{July} 1943$, Dugand \& Jarami110 3422 (COL); MAGDALENA: Santa Marta region, 1931, Espina 61 (F); Don Jaca, 'smooth dark brown bark, wood hard", 20 Jan. 1930, Record 63 (F, NY); Santa Marta, $150 \mathrm{~m}$. alt., Jan. 1901, Smith 208 $(G, S, U S)$, VENEZUELA: PORTUGUESA: Agua Blanca, 24 April 1948, Turner $145(\mathrm{~F})$.

7b.

Astronium graveolens var. dugandij Barkl., … var.

Speciei simile, sed foliola ovatiora, minus numerosa; folia subglabra.

Tree 10 to 15 meters tall, the branches tannish; the leaves with about $?$ leaflets, the leaflets glabrous or with very few hairs on the midveins below, ovate, inequalateral, abruptly acuminate at the apex, subobtuse, the margins subentire to obscurely serrate, 5.5 to $8.5 \mathrm{~cm}$. long, 2.5 to $4.5 \mathrm{~cm}$. broad, petiolules about $3 \mathrm{~mm}$. long, subglabrate; the inflorescences panicles, produced in the uppermost nodes after leaves have fallen, the lateral panicles in the bud subtended by a rotund, caducous, glabrous except marginally ciliate bract, the smaller branchlets subtended by small oblanceolate bracts (the larger bracts $3 \mathrm{~mm}$. long, $2.5 \mathrm{~mm}$. broad, the smaller ones $3 \mathrm{~mm}$. long, $2 \mathrm{~mm}$. broad and the smallest $1.5 \mathrm{~mm}$. long. $.4 \mathrm{~mm}$. broad); pedicels slender. 
3 to $5 \mathrm{~mm}$. long, glabrous; the sepals glabrous, $1 \mathrm{~mm}$. long, $.8 \mathrm{~mm}$. broad; the petals obovate, glabrous, persistent in fruit, $2 \mathrm{~mm}$. long, $1.2 \mathrm{~mm}$. broad; the filament slender, $2 \mathrm{~mm}$. long, anther. $8 \mathrm{~mm}$. long, $.4 \mathrm{~mm}$. broad, oval; the sepals in fruit oblanceolate, glabrous, 1.1 cm. long, $3.5 \mathrm{~mm}$. broad.

Type: Colombia: Atlántico: along Arroyo Bañón, 100 m. alt., 14 May 1936, A. Dugand 218 in the phanerogamic herbarium of the Chicago Natural History Museum.

This variety seems to be intermediate between Astronium graveolens and A. fraxinifolium var. glabra.

Common names: "Quebracho", "Quebracho Blanco", "Quebracho Morado", "Santacruz".

Distribution: Barranquilla region of Colombia.

Specimens examined: COLOMBIA: ATLANTICO: Bohórquez region near Giralda, 1933, --- 493: 157 (F); along arroyo Bafion, $100 \mathrm{~m}$. alt., "common tree, 10-15 meters, dark gray bark with lighter blotches", 14 May 1936, Dugand 218 (F--Type) and between Arroyo de Piedras and Luruaco, 4 May 1936, 277 (F) and 978 (F); 100-200 m. alt., $25 \mathrm{Feb}$. 1936, Dugand \& Mina 239 (F); BOLIVAR: Corozal, Corregimiento Palmitas, 2,5 Aug. 1944, Gutierrez 18 (COL) and 34 (COL); MAGDALANA: Banda, 100 a 200 m. alt., Feb. 1948, Romero 698 (COL).

8. Astronium conzattii Blake, Contr. Gray Herb. n.s. 53: 59.

1918.

Astronium zongolica Reko, 트 Mexico Antiguo 1: 157. 1918.

Tree with glabrous branches; leaves imparipinnately compound with about 9 leaflets; leaflets ovate-lanceolate, acuminate, rounded obtuse at base, obscurely serrate, very sparsely pilose, $1.5-2.5 \mathrm{~cm}$. broad, 3$6 \mathrm{~cm}$. long; petiolules minutely pilose, about $5 \mathrm{~mm}$. long, rachis segments minutely pilose, about $2 \mathrm{~cm}$. long; petiole minutely pilose about $4.5 \mathrm{~cm}$. long; thyrsus or terminal panicles produced from the uppermost noedes of the branches, the axis glabrous; sepals (of the staminate flowers) orbicular, $.5 \mathrm{~mm}$. in diameter, glabrous; petals obovate, rotund-glabrous, $1 \mathrm{~mm}$. broad, $1.5 \mathrm{~mm}$. long.

Type: Mexico: Oaxaca: Pochutla: Capital Concordia, $600 \mathrm{~m}$. alt., April 1917, Conzatti, Reko \& Makrinius 2051 in the Gray Herbarium of 
Harvard University.

This species is very similar to some of the specimens of Astronium graveolens, and it perhaps should have been treated as a variety of the species, however it seems best to treat it as a distinct species.

Common names: "Gateado", "Zongalia", "Zongalica".

Distribution: Southern Mexico and adjacent Central America.

Specimens examined: MEXICO: OAXACA: Pochutla: $600 \mathrm{~m}$. alt., 10 April 1917, Conzatti, Reko \& Makrinius 2051 (GH--Type, MEXU); Mena, $20 \mathrm{Jan} .1927, \frac{\mathrm{MeII}}{6}$ (US) and $\underline{\mathrm{S.n} . \mathrm{NY}}$ ); Cafetal Concordia, 400-650 m. alt., 1-15 April 1933. Morton \& Makrinius 2436 (F, MICH, US) and 2601 (F, MICH, US); Caf etal Concor dia, 1917, Reko 4192 (Lis); GUERRERO: near Acapulco, $15 \mathrm{Feb}$. 1921, Gamon 19 (US); CENTRAL AMERICA:

BRITISH HONDURAS: BI Cayo: Limestone hill near Valentin, June-July 1936, Lundell 6339 (F, MICH, NY).

\section{8a. Astronium conzattil var. lundellii Barkl., n. var.}

Speciei simile, sed foliola brevius acuminata, minus acute serrata et infra velutino-pilosa.

Tree; branches terete, slender, at first subglabrous; leaves imparipinnately compound with about $?$ to 9 leaflets, 15 to $20 \mathrm{~cm}$. long, leaflets subserrate lanceolate, acuminate at apex, obtuse at base, finely pilose above, velvety pilose below, $1.5-2.5 \mathrm{~cm}$. broad, $4.5-7.5$ $\mathrm{cm}$. long, petiolules about $3 \mathrm{~mm}$. long, finely pilose; inflorescence a terminal thyrsus and panicles in the axils of the uppermost leaves; fruit with calyx lobes oblanceolate, rounded obtuse, glabrous, $3 \mathrm{~mm}$. broad, $1.2 \mathrm{~cm}$. long, petals $1.8 \mathrm{~mm}$. long, obtuse, ovary $1.2 \mathrm{~cm}$. long. $3 \mathrm{~mm}$. in diameter.

Type: Guatemala: Peten: La Libertad, 19 April 1933, C. L. Lundell 2881 in the United States National Herbarium.

This variety is similar to the typical variety except is much more pilose. The two specimens from Costa Rica may represent a distinct variety, but unfortunately the specimens were recalled from loan before their study could be completed.

Distribution: Guatemala and Costa Rica.

Specimens examined: CENTRAL AMERICA: GUATEMALA: Petén: Chicbul: 
La Libertad, 19 April 1933, Lundell 2881 (F, G, MICH, S, US) and 29 April 1933, 3095 (F, MICH, US); COSTA RICA: entre los rios Pilas y Tacares en la carretera de Alajyela a Grecia, 22 oct. 1933, Brenes 43 (F) and camino de Canãs a Tilacan Guanacaste, 28 June 1930, s, $n_{2}(F)$.

8b. Astronium conzattij var. standleyi Barkl., n. var.

Speciei simile, sed foliola longiora, acutius serrata, general-

iter longius acuminata, fere glabra.

Tree with glabrous branches; leaves imparipinnately compound with leaflets 15-19; leaflets lanceolate, long acuminate, subcuneate to rounded at the base, $1.5-2.5 \mathrm{~cm}$. broad, 5-9 cm. long, finely serrate, glabrous or very finely and sparsely pilose; shortly petiolulate, finely pilose on petiolules about $4 \mathrm{~mm}$. long; rachis segments subglabrous (microscopically very sparsely pilose), about $3 \mathrm{~cm}$. long; petiole about $6 \mathrm{~cm}$. long, glabrous.

Type: Central America: Panama; Near Matías Hernández, 30 Dec. 1923, Standley 28942 (US).

The author has seen neither flowering nor fruiting material of this widely distributed variety. It seems most similar to the somewhat pubescent var. conzattii.

Distribution from Mexico through Panamá to Venezuela.

Specimens examined: MEXICO: VERA CRUZ: Fortuño: Coatzacoalcos River, $3050 \mathrm{~m}$. alt., March 1937. Williams 8753 (F); CHIAPAS: Cacaluta: Escuintla, $24 \mathrm{Feb}$. 1947, Matuda 1645 (F) and 15 April 1947, 16518 (F, MEXU); OAXACA: Usumazin, Valle Nacional, $150 \mathrm{~m}$. alt., 1919, Reko 4192 (US); Choapan: Monte Negro de Lalma, 150 m. alt. , 3 May 1939, Schultes \& Reko 769 (MEXU); Ubero, 30-90 m. alt., June 1937, Williams 2517 (F); YUCATAN: 1917-1921, Gaumar 24171 (F, US); CENTRAL AMERICA: GUATEMALA: Alta Verapaz: woods southeast of Finca Valpemech, 100-150 m. alt., 'tall forest tree with very fine wood with yellow and brown grain; this specimen from a sapling", 23 March 1942, Steyermark 4520 (F); Chiquimula: 4-6 miles north of Chiquimula between Santa Barbara and Petapila, 22 oct. 1939, Steyermark 30268 (F); Quebrada Shusko above Chiquimula, $480 \mathrm{mo}$. alt., 14 Oct. 1940, Standley 24308 (F); Gyatemala: Aguilar 634 (F); Huehuetenango: Paso del Boqueron along Río Trapichillo below La Libertad, 1200-1300 m. alt., 21 Aug. 1942, Steyermark 21167 (F); Izabal: vicinity of Quirigua, 75-225 m. alt., 15-el May 1922, Standley 23947 (US); between Bananera and "La Presa" in Montaña del Mico, 40,-300 m. alt., 28 March 1940, Steyermark 38094 (F) and 38145 (F); Petén: forest between Finca Valpemech along Rio San Diego and San Diego on Río Cancuen, 50-150 ma alt., 25 March 1942, 
Steyermark 45306 (F, GH), along Río Machaquila north of El Cambio, 75-100 m. alt., 25 April 1942, S.n. (F), and Cerro Ceibal (Chorro Ceibal, Sierra Mojada, or Cerro San Martín) between mouth of Río Santa Mónica and mouth of Río San Martín, 75-150 m. aft., 3C April 1942, Steyermark 46117 (F); Zapaca: along Rio Teculatan above Teculatán, 250-275 m. alt., ? Jan.. 1942, Steyermark 42144 (F); Sololá: south facing slopes of Volcan Atitian, 1700-380J $\mathrm{m}_{2}$ alt., 11 June 1942, Steyermark 47338 (F); EL SALVADOR: Ahuachapan: near Salto de Atehuecia, $600 \mathrm{~m}$. alt., "dry forested hillside", 22 Jan. 3947, Standley \& Padilla 2865 (F); Santa Ana: vicinity of Metapan, $370 \mathrm{~m}$. alt., "small tree on dry, rocky, bushy hillside" 29 Jan.-1 Febr. 1947. Standley \& Padilla 3218 (F); HONDURAS: Atlantida: Iancetilla Valley near Tela, 20-600 m. alt., 6 Dec.-20 March 1927, Standley 53883 (F, GH, US), 23984 (F, GH, US), 54065 (F, GH), and 54680 (F, GH, US); Comayagua: viçinity of Comayagua, $600 \mathrm{~m}$. alt., 12-23 March 1947. Standley \& Chacoon 5767 (F); Copan: La Frarcia, 6 May 1919, Whitford \& Stadtmiller 20 (US); Santa Barbara: near Jutiapa, $180 \mathrm{~m}$. alt., 16 April 1947, Standley \& Londelie 7287 (F); Yoro: near Progreso, 26 March 1929, Hottle 22 (F); near Progreso, 24 Jan. 1928, Standley 55097 (F, GH, US); COSTA RICA: Guanacaste: vicinity of Iibano, 260-360 m. alt., $15 \mathrm{Jan}$. 1926, Standley \& Valerio 44916 (US); PANAMA: Canal Zone: Barro Colorado Island, $15 \mathrm{~N}$ ov. 1931, Shattuck $632(F)$ and 20 March 1932, 866 (F); Río Pedro Miguel near Fast Paraíso, 7 Jan. 1924, Standley 29951 (US); Panamą: Río Tąpia, 7 Dec. 1923-17 Jan. 1924, Standley 26183 (US), near Matias Hernandez, 30 Dec. 1923, 28942 (US-Type); Rio Tocumen, 3 Jan. 1924, 29377. (US), and Juan Diaz, 11 Jan. 1924, Standley 20550 (US); South Darien: EI, Real de Santa Maria, June 1914, Pittier 6997 (US); Camarca del Barú, $100 \mathrm{ft}$. elev., 15 June 1957, Stern \& Chambers 129 (GH); COLOMBIA: BOLIVAR: Landas de Loba: San Martin de Lobą and vicinity, April-May, 1916, Curran 188 (US); BOYACA: Valley of Río Negro, Guaguaqui, 170 m. alt., 14 July 1917, Whitford \& Pinzon 15 (GH); MAGDALENA: Tucurinca, $100 \mathrm{a} 200 \mathrm{~m}$. alt., Dec. 1947, Romero s.n. (COL); VENEZUELA: CARABOBO: vicinity of Las Trincheras near Valencia, $200-400 \mathrm{~m}$ alt., 30 Dec. 1917, Pittier 2650 (US, VEN); GUARICO: $19 \mathrm{Feb} .1924$, Pittier 11435 (G, VEN).

9. Astronium mirandait Barkl., n. sp.

Astronium fraxinifolium Standley, Contr. ‥ S. Nat. Herb. 23: 1671. 1926, 포. ‥

Arbor; rami primum pilosi; folia impari-pinnata, 2-11 foliolis composita; foliola anguste ovata, acuminata, rotundata et in basi tantum inaequalia, dense pilosa, subserrata usque integra, breviter petiolulata; fructus glaber; sepala $12 \mathrm{~mm}$ longa $5 \mathrm{~mm}$ lata, late

+ Named for the late Dr. Faustino Miranda of Mexico. 
oblanceolata; petala $1.5 \mathrm{~mm}$ longa. $8 \mathrm{~mm}$ lata; ovarium $12 \mathrm{~mm}$ longum. 2 im latume fusiforme.

Tree; branches brownish, Dilose; leaves imparipinnately compound with about 9-11 leaflets; leaflets 6-11 cm. long, 2.6-3.3 cm. broad, narrowly ovate, acuminate, rounded and slightly unequal at base, densely pilose, subcrenulate-serrate to entire, shortly petiolulate on pilose petiolules $4 \mathrm{~mm}$. long; inflorescence a terminal thyrsus about $20 \mathrm{~cm}$. long, with or without panicles at the uppermost nodes, sparsely long pilose; sepals in fruit glabrous $12 \mathrm{~mm}$. long, $5 \mathrm{~mm}$. broad, broadly oblanceolate and obtuse at apex, the petals oblandeolate, glabrous, narrowed above, $.8 \mathrm{~mm}$. broad, $1.5 \mathrm{~mm}$. long, the ovary fusiform, $1.2 \mathrm{~cm}$. long, $2 \mathrm{~mm}$. broad.

Type: Mexico: Vera Cruz: Remudadero, April 1922, C. A. Purpus 8761 in the Herbarium of the United States National Museum.

known only from the type locality.

Specimens examined: MEXICO: VERA CRUZ: Remudadero, April 1922, Purpus 8761 (GH, NY, US--Type); Los Conejos, March 1935, Purpus 16429 $(\mathrm{F}, \mathrm{GH})$.

10.

Astronium gardneri Mattick, Berlin Bot. Gart. Notizblatt 11:

1007. 1934.

Tree; branches terete, at first grayish brown, pilose, later glabrate and brown; leaves compound, pilose, with 5 to 9 leaflets; leaflets narrowly ovate or oblong ovate, subacute to actue at apex, obtuse at base and very unequal, entire; fruit $1.3 \mathrm{~cm}$. long.

Mattick's original description for this species was: "Astronium Gardneri Mattick n. sp. Ramuli teretes, novelli dense flavide holosericeo-pilosi, demum glabri, purpurascentes. Folia imparipinnata, 2-4-juga, 8-12 cm longa, inter jugis 1,5 ad $2 \mathrm{~cm}$ longis, petiolis et petiolulis dense et molliter holosericeis. Foliola petiolulis $2-3 \mathrm{~mm}$ longis, oblique ovata vel ovato-oblonga subacuta, integerrima, 2,5 4,5 $\mathrm{cm}$ longa, 1,5-2 cm lata, supra sparse, subtus praecipue in costa et venis subdense pilosula, nervis lateralibus 7-10 paulum prominulis. Paniculae quam folia longiores, $15-20 \mathrm{~cm}$ longae lataeque, pyramidatae, ramulis teretibus, imprimis rachi, minus ramulis lateralibus pilosulae. Flores masculi ignoti. Pedicelli f ructus $1,5-2 \mathrm{~cm}$ longi. Calycis feminei fructiferi segmenta oblonga, quam petala sexies longiora, 
10-12 mm longa, 3-4 mm lata. Petala ovalia, $2 \mathrm{~mm}$ longa, $1 \mathrm{~mm}$ lata. Fructus oblongo-acutus, lacinias calycinas auctas aequam, 10-12 mm longus, $3 \mathrm{~mm}$ crassus, apiculatus."

The author has examined the isotype from the New York Botanical Garden which shows immature leaves and has a few fruits. The leaves are very similar to those of $A_{0}$ urundeuva, but the fruit are typical of Euastronium.

Type: Brazil: Piauhy: August 1839, Gardner 2520 in the Herbarium of the Royal Botanic Gardens, Kew.

Specimens examined: BRAZII: Igreja Velha, 1841, Blanchet 3418 (NY); MARANHÃO: Barra do Corda, $20 \mathrm{July} \mathrm{1909,} \mathrm{Lisboa} \mathrm{s.n.} \mathrm{(MG);}$ Carolina, 30 July 1949, Murça \& Black 1573a (BEL); MINAS GERA ËS: Bello Horizonte, Carlos Prates, 17 Nov. 1941, Mendes 241 (BEL); PIAUHY: 1841, Gardner 2520 (GH, K).

II. Subgenus Myracrodruon (M. Fr. Allemão) Barkl., n. stat.

Myracrodruon M. Fr. Allemão, Trab. Bot. 1: 3. 1862; Fngler in Martius \& Eichler, Flora Brasil. $12^{2}: 400$. 1876.

Fruit oblong, apiculate, the mesocarp thickish and resinous, the calyx lobes are much longer than the ovary, the seed subreniformorbicular.

This subgenus ranges from central Brazil to Bolivia, Paraguay and Argentina; its few species are comparatively well represented in herbaria and therefore present less problems taxonomically.

IIa. Section Eumyracrodmuor, n. sect.

Myracrodruon M. Fr. Allemão, Trab. Bot. I: 3. 1862.

Section Myracrodmuon Engler in DC., Monog. Phaner. 4: 453. 1883, excl. A. concinnus and $A_{0}$ macrocalyx.

Fructus sphaericus, endocarpio osseo; sepala calycem circumdantia minus quam $1 \mathrm{~cm}$. longa.

Fruit globose-spherical, endocarp long; calyx segments less than

$1 \mathrm{~cm}$. long.

This section consists of two species and a very distinctive variety, which are among the best known and easily recognizable of the genus. 
11. Astronium urundeuva (Fr. All.) Engl., Bot. Jahrb. 1: 45. 1881; Mattick, Berlin Bot. Gart. Notizblatt. 11: 1009. 1934; Cabrera, Rev. Mus. La Plata n.s. 2: 46. 1938.

Myracrodruon Urundeuva M. Freire Allemão, in F. Fr. Allemão \& M. Fr. All emão, Trab. Comm. Sc. Expl. Bot. I: 3. 1862; Engler in Martius \& Eichler, Flora Brasil 12 1200 . 1876 . 1879.

Astronium juglandifolium Griseb., Symb. ad Flor. Argent. 94.

A tree to about 25 meters, the young branches green, densely pilose, at length glabrate; leaves imparipinnately compound, leaflets 5 to 15, softly pubescent, the leaflets elliptical, narrowly ovate, or broadly landeolate, subacute to acute at the apex, rarely obtuse, obtuse at base or rarely broadly cuneate, petiolules pilose, 2 to 4 mm. long, rachis segments pilose 1 to $2 \mathrm{~cm}$. long, the petiole pilose, 3 to $4 \mathrm{~cm}$. long; inflorescences panicles axillary to the uppermost leaves and usually produced after these leaves have fallen, 5 to 15 cm. long; bracts small, deltoid ovate, glabrous, caducous; the flowers sessil? at anthesis; sepals spherical, glabrous except ciliolate on the margin, $.4 \mathrm{~mm}$. long, $.5 \mathrm{~mm}$. wide; petals ovate, glabrous or with 2 or 3 cilia on the margin, $1 \mathrm{~mm}$. wide, $2 \mathrm{~mm}$. long; the stamens in staminate flowers with slender filaments $2 \mathrm{~mm}$. long, the anthers ovate, .7 mm. long, .3 m. broad; the disk 5-lobed, thr. ovary rudimentary; (in the pistillate flowers the stamens slightly smaller, but the pistil ovoid, $.3 \mathrm{~mm}$. long, .2 mm. broad, the stigmas sessile;) in fruit the sepals enlarged, obovate, truncate, glabrous except a few cilia on the margin, $7 \mathrm{~mm}$. long, $3 \mathrm{~mm}$. wide; the fruit sphericai, brownish black, about $4 \mathrm{~mm}$. in diameter; exocarp thin and glabrous, adherent to the thin, resinous mesocarp which in turn is adherent to the rough bony endocarp; the sesd 3.2 mm. broad, $3 \mathrm{~mm}$. high, irregular in outline, lenticular, $1 \mathrm{~mm}$. thick except in the region of two prominent protuberances $2 \mathrm{~mm}$. thick.

Type: The author has interpreted Glaziou 12543 from Rio de Janeiro as the type of the species. 


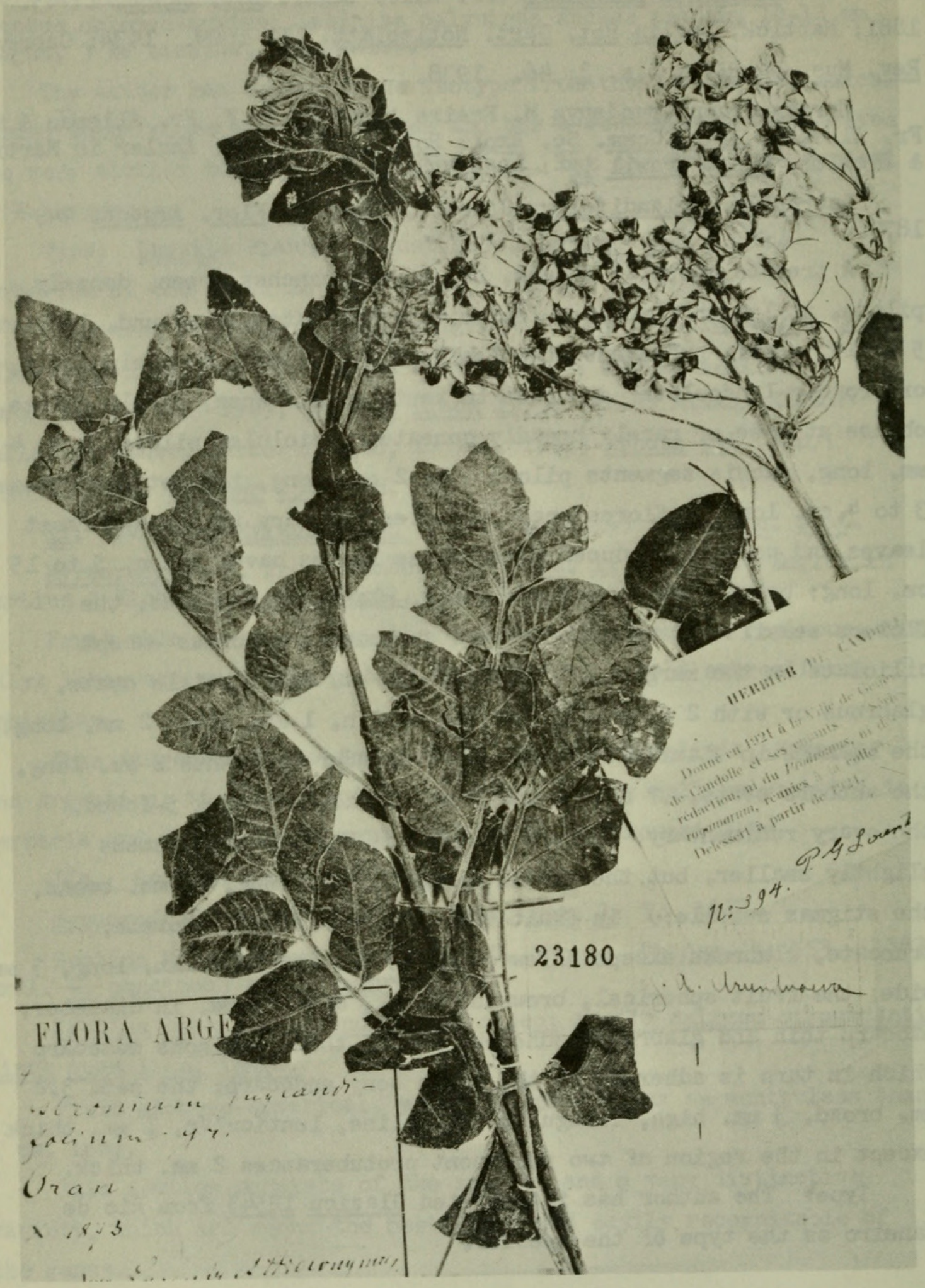

PLATE IV. Photograph of Astronium urundeuva (Fr. A11.) Engler from Lorentz \& Hieronymus 394 in the Geneva Herbarium. Note the shape of the fruit. (Photo courtesy of the Field Museum of Natural History, Chicago.) 
This is a very characteristic tree with pilose leaves. The variety candollei is quite distinctive, yet appears as the glabrous equal of the species.

Common names: "Aroeira", "Aroeira preta", "Aroeira de Campo", "Chibatan", "Gibatão", "Sotocele", "Ubatan", "Ubatão", "Urindeuva", "Urundel", "Urundeuva", "Urundey", "Urundeý-mín".

Distribution: coastal regions south of the Amazon in Brazil

to Bolivia, Paraguay and northern Argentina.

Specimens examined: BRAZIL: Pará Barrado Corda, 20 July 1909, Aerojado 2459 (G); Brejã̀, Ang. 1912, Zehntner 319 (R); BAHIA: Catinga, 1906, Ule 7283 (G); CEARÁ: Allamão $\mathrm{s}_{.} \mathrm{n}_{\mathrm{e}}(\mathrm{R})$; Grunada, 6 July 1908, Ducke s.n. (MG), Baturite, 11 Sept. 1908, S, no (MG) and Guaramiranga, 23 April 1909, Ducke s.n. (MG); MINAS GERAES: 1836, Claussen $473(N Y, S)$ and $1840, \mathrm{s,n},(G)$; entre Barbacena y Sitio, 4 August 1879, Glaziou 12943 (US); GOYAZ: Passa Tres a João Loba, 1894. Glaziou 20869 (F, G, S); Ituiutaba, 4 Aug. 1944, Macedo 457 (SP); Santa Luzia, Gorduras de Baiso, 15 Aug. 1942, Nestor s.n. (BEL); MATTO GROSSO: Corimba, $30 \mathrm{Aug}$. 1892, Kuntze s.n. $n_{0}(\mathrm{NY}) ;$ ESPIRITU SANTO: Leopoldina, Oct. 1917, von Luetzelburg 12001 (NY); RIO DE JANEIRO: Rio de Janeiro, 1882, G1aziou 12543 (G--Type?); SÃO PAULO: Corumbatahy, July, Cépolla II-190 (R, SP); Bebedoura, June-July 1936, Jordão 301 (SP); Villamontes, 1924-1925, Pflanz 4085 (US); BOLIVIA: Berme jo, 1500 m. alt., 23 Nov. 1903, Fiebrig 2198 (G, LP, S) and $S_{.} n_{0}$ (US); Gran Chaco, Tatarenda, 19 March 1902 , Fries 1409 (S, USO; Velasco, $300 \mathrm{~m}$. alt., July 1892, Kuntze s.n. (NY); LA PAZ: S. Yungas: near Calisaya, basin of Rio Bopi, 1-22 July 1939, Krukoff 10259 (NY); SANTA CRUZ: Sara: Bosques del Lomerio, $450 \mathrm{~m}$. alt., $20 \mathrm{Feb}$ 1926, Steinbach 247 (BA, F, GH, LIL, NY, S); Urubé: Cercado, $450 \mathrm{~m}$. alt., 15 Aug. 1927. Steinbach 2921 (F, GH, LIL, NY); PARAGUAY: Chaco Paraguayo, 210 lat., 1906, Fiebrig 1271 (G); 1932, Jorgensen 39c2 (F, GH, NY, S, US); Chaco Paraguayo Palmas Chicas, Dec. 1937, Rojas 2712 (LP); CARAGUATAY: Monte Ciervo-cua, Aug. 1890, Hassler 1890 (G) and 1890a (G); CONCEPCIÓN; Prope Concepcion, Aug. 1901, Hassler $\overline{215}$ (G); PARAGUARI: prope Sapucay, Oct. 1913, Hassler 11890 (G, UC, US) and 11890a (G, UC, US); ARGENTINA: JUJUY: quinta cerca Laguna de la Brea in silva densa, 10 Aug. 1901, Fries 456 (S); 13 Dec. 1906, Lillo 5277 (IIL) and cerca de la fonda de Bartolo, 24 Dec. 1906, 5279 (LIL); Oct. 1940, Schreiter 11381 (GH, LIL); Sierra de Calilegua, 750 m. alt., 14 oct. 1927 , Venturi 5417 (BAB, F, LIL, NY, SI, US) and Sierra Calilegua, $750 \mathrm{~m}$. alt., 25 Oct. 1930, 10609 (SI); San Lorenzo: en selva alta, 25 Oct. 1890, Schulz 8170 (CORD); San Pedro: La Ba jada, 100 m. alt., 10 Oct. 1932, Pastrana 2135 (IIL); cerro de San Pedro, 800 m. alt., 10 Oct. 1925, Schreiter 5018 (III) and $600 \mathrm{~m}$. alt., 5 oct. 1925, 5028 (III); 
Sierra Sant Bárbara, 700 m. alt.. 16 oct. 1929, Venturi 9698 (GH, LP, NY, S, US), Cerro de San Pedro, 800 m. alt., 10 Sept. 1926, 5033 (GH, SI, UC, US pr.p.); San Pedro de Jujuy, $640 \mathrm{~m}$. alt., "árbol de medio metro de diametro, 8 de altura que crece en los bosques", 20 Oct. 1930, Venturi 10632 (SI); Santa Bárbara: Sierra de Santa Bárbara, 3 Jan. 1911, Spegazzini 1490 (LP); SALTA: El Querucillal, Nov. 1937, Devoto \& Rial S.n. (BABOsq); Anta: Represa de Concha, finca El Yeso, 25 May 1946, Meyer 9871 (IIL); Cerro la Ronda. June 1934, Ragonese 318 (BA, F); Oran: Rio Pescado, 26 Sept. 1946, Castiglioni \& Tinto 2967 (BABosq), 27 Sept. 1946, 2968 (BABosq), 20 Sept. 1946, 2969 (BABosq), 19 Sept. 1946, 2920 ( $\overline{\mathrm{BABO}} \mathrm{sq})$ and $27 \mathrm{Sept.} 1946$, Castiglioni \& Tinto 2971 (BABosq); San Ignacio, 20 .4ug. 1944, Claps 299 (IIL); Febr. 1916, Hauman (BA), and Feb. 1923, s.n. (BA); Embarcacion, April 1911, Jörgensen S.n. (BAB); 21 Feb. 1916, Lillo 18087 (IIL); Tabacal, 18 June 1873, Lorentz \& Hieronymus s, n. (CORD), 16 oct. 1873, 394 (CORD, G--Isotyles of Ao juglandifolinm Griseb.), Oct. 1873, 418 (CORD) and oct. 1873, Lorentz \& Hieronvmus s.n. (CORD, UC); Campamente Y.P.F. Río Pescado, $420 \mathrm{~m}$. alt., 26 Febr. 1943, Meyer 4886 (III, UC) and Tartagal, 2 Nov. 1947, Meyer 12663 (IIL); Rio Piedras, 31 Nov. 1911, Rodriguez 133 (BA, FacCBA, LIL, SI); Tartagal, $500 \mathrm{~m}$. alt., 1 Oct. 1925, Schreiter 28 (BA); Tartagal, 500 m. alt., Oct. 1940,11380 (F, GH) and Schreiter 11382 (LII); Tartagal (San Jorge), $24 \mathrm{July} \mathrm{1944}$, Schulz \& Varela 5386 (IIL) and 5388 (LIL); Embarcacion, 22-23 Nov. 1909, Venturi 316 (LIL) and Tartagal, 500 m. alt., 1 Oct. 1926, 5043 (BA, F, GH, S, SI, US); Rivadavia: Río Tarija, Oct. 1938, Carmelich \& Rial 366 (BABosq).

1la. Astronium urundeuva var. candollei (Engl.) Hassl. ex Mattick,

Berlin Bot. Gard. Natizblatt 11: 1011. 1934; Cabrera, Rev. Mus. La Plata n.s. 2: 47.1938.

Astronium Candollei Engl., Bot. Jahrb. 1: 45. 1881; Engl. in DC. Monog. Phaner. 4: 458. 1883; Hassler \& Chodat, Bull. Herb. Bois. II, 1: 68. 1903 ; Hassler \& Chodat, Bull. Herb. Bois. ․․․

Tree; branches slender, grayish-brown, glabrous; leaves compound, 20 to $25 \mathrm{~cm}$. long; leaflets 7 to 13, about $5 \mathrm{~cm}$. long, about $2 \mathrm{~cm}$. broad, glabrous except sparsely pubescent on the veins, acute at the apex, very finely subserrate to subentire, except terminal unequally obtuse to subcuneate at apex, petiolulate with petiolules about $3 \mathrm{~mm}$. long; panicles axillary to the uppermost leaves, 3 to $8 \mathrm{~cm}$. long; flowers subsessile; sepals glabrous, obovate, $.9 \mathrm{~mm}$ long, $4 \mathrm{~mm}$. broad; petals glabrous, $1.8 \mathrm{~mm}$. long, $1 \mathrm{~mm}$. broad; fruit spheroidal, $4 \mathrm{~mm}$. in diameter, the calyx wings $6 \mathrm{~mm}$. long, $3 \mathrm{~mm}$. broad, obtuse. 
Type: Paraguay: Paraguari: in silvis Cerro-Hú, Balansa 2528 in the De Candolle Herbarium of the Institut de Botanique Systématique de I'Université de Genève.

This variety is very similar to the typical variety except it is glabrous in all parts.

Common names: "Aroeira", "Urundei-mi".

Distribution: Paraguay and northern Argentina.

Specimens examined: PARAGUAY: Chaco septentrionalis, 1907. Fiebrig 127 (G); CARAGUATAY: cerrito San,Bernardino, Aug., Hassler 12202 (G, UC); PARAGUARI: Cerro Hú, ? Oct. 1875, Balansa $2528(G--$ Type $)$ and Oct. 1881, 2265 (G); Prope Sapucay, Jan. 1913, Hassler 12202a (G, UC, US); ARGENTINA: JUJUY: Ledesma, Ell Sanjal, 17 April 1911, Lillo s.n. (III), 5 JuIy 1911, 10789 (LII) and I Nov. 1911, 10842 (GH, IIII); 17 April 1911, Stuckert 22341 (III); SALTA: Orán: Zanja Honda, Tartagal, $500 \mathrm{~m}$. alt., 26 Jan. 1924, Schreiter 2390 (LIL, US), I Oct. 1925, 2028 (LIL) and Oct. 1940, schreiter $\underline{11382}$ (LIL).

12.

Astronium balansae Fngl., Bot. Jahrb. 1:45. 1881;

Engl. in DC., Monog. Phaner. 4: 459. 1883; Mattick, Berlin Bot. Gard. Notizblatt 11: 1011. 1934; Cabrera, Rev. Mus. La Plata n.s. 2: 44. 1938.

Tree 5 to 15 meters tall with thin, glabrous, brownish branches; the leaves imparipinnately compound, 9 to 15 leaflets; leaflcts glabrous, lanceolate, sometimes broadly so, acuminate at apex, broadly subcuneate at the base, finely and sharply serrate, darker above, 3-6 cm. long, 9-2.2 cm. broad, the petiolules slender, glabrous, .9 to $1.3 \mathrm{~cm}$. long, rachis segments glabrous, slender, 2 to $4 \mathrm{~cm}$. long, petiole glabrous, 4.5 to $7.5 \mathrm{~cm}$. long; the inflorescence a terminal thyrsus or lateral panicle, these 8 to $12 \mathrm{~cm}$. long, quite glabrous; bracts glabrous except glandular ciliate on the margin, deltoid-lanceolate, $.6 \mathrm{~mm}$. wide, 1 to $1.5 \mathrm{~mm}$. long, caducuous; pedicels at first sparsely glandular pubescent, soon glabrous; sepals ovate, glabrous, obtuse, $1 \mathrm{~mm}$. long, $.8 \mathrm{~mm}$. wide; the petals ovate to obovate, $2 \mathrm{~mm}$. long, $1 \mathrm{~mm}$. wide; the stamens shorter than the petals, filaments $1.1 \mathrm{~mm}$. long, anthers oblong, $.8 \mathrm{~mm}$. long, .2 mm. broad; 


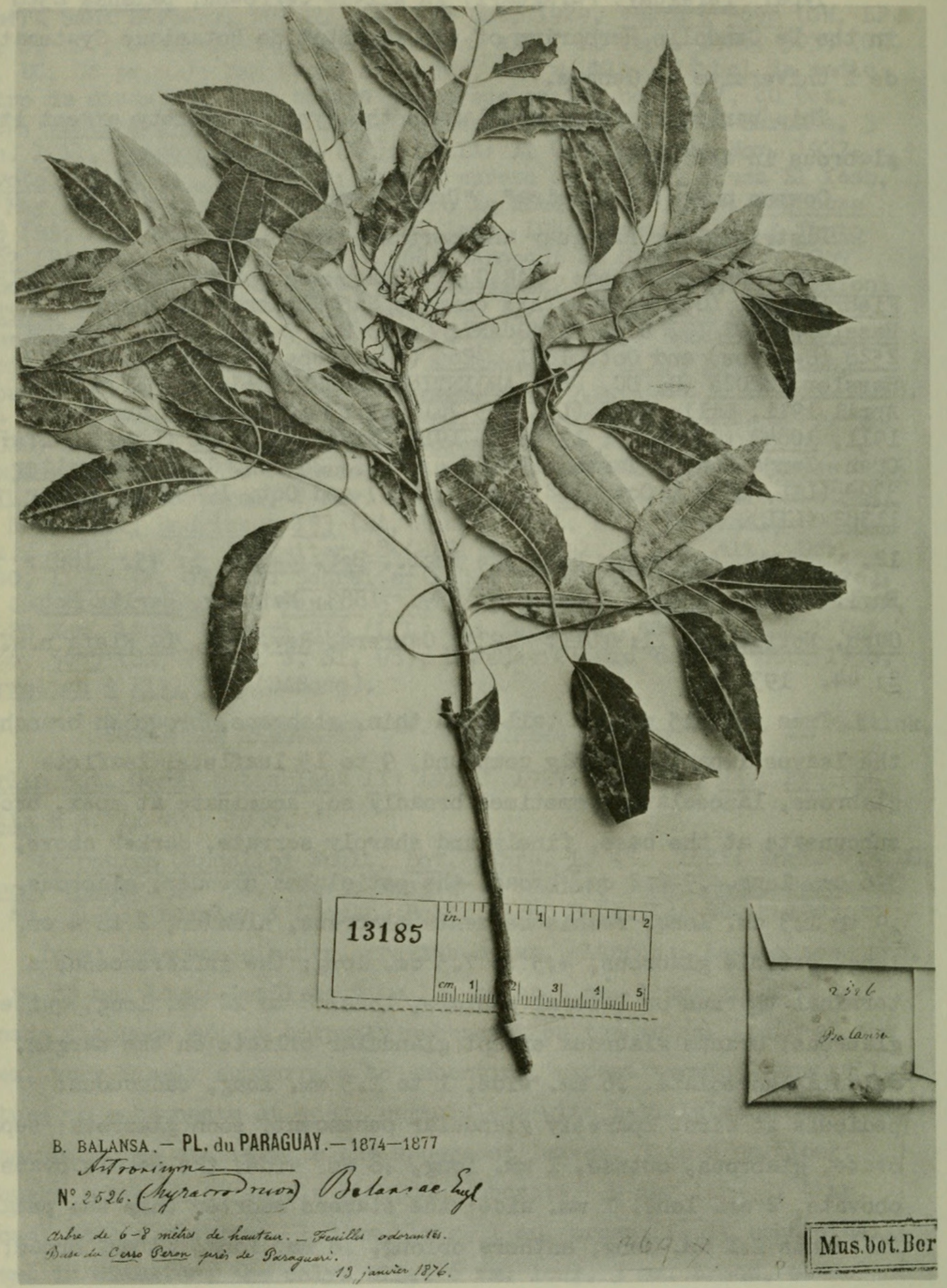

PLATE V. Photograph of Astronium balansae Engler from Balansa 2526 in the Berlin Herbarium. Note the long petiolules and very assymetric leaflets. (Photo courtesy of the Field Museum of Natural History, Chicago.) 
the pistil (in the staminate flowers) minute; the sepals in fruit obovate about $4 \mathrm{~mm}$. long, $2.5 \mathrm{~mm}$. wide, the filaments $.5 \mathrm{~mm}$. long, the disk $1 \mathrm{~mm}$. in diameter; the fruit black, glabrous, spherical, 2.5 to $3 \mathrm{~mm}$. in diameter.

Type: Paraguay: Paraguari: Cerro Peron, 13 Jan. 1376, B. Balansa 2526 in the De Candolle Herbarium of the Institute de Botanique Systématique de I'Université de Genève.

This species is a very striking one, in which the leaflets are long petiolulate and therefore easily recognizable from the other species.

Common names: "Curupach", "Pae Ferro", "Urundahy", "Urunday colorado", "Urunday-pardo", "Urunday-pita", "Urundeíh-mí", "Urundel", "Urundey", "Urundey-pichai".

Distribution: northeastern Argentina and Paraguay.

Specimens examined: PARAGUAY: Corrientes, Jan. 1882, Balansa 3188 (G); 1833, Bonpland 497 (F); Puerto Yataybá, 14-15 Sept. 1928, Daguerre s.n. (BA); ENCARNACIÓN: Encarnación, Jan. 1944, Pavetti \& Rojas 10931 (IP) and 10931a (IP); Combyreta, Jan. 1944, Rojas 10931 (LIL) and 10931a (III); FARAGUARI: Base du Cerro Perón, 13 Jan. 1876, Balansa $25 \overline{26}(\mathrm{BAF}, \mathrm{G}--\mathrm{Type})$; Carapegua, Febr. 1919, Rojas 3460 (IIL, LP), $3460 a$ (LIL); VILLETA: San Fernando, 4 May 1945, Rojas 12642 (AS, LII); ARGENTINA: '97, Bonpland s.n. (RB); FORMOSA: Jan. 1918, Jorgensen 2056 (BA, GH, LIL, SI, US); Delicia, 8 Jan. 1947, Reales 12.7 (LIL); Sept. 1902, Villa s.n. (BAF); Formosa: Mojón de Fierro, $?$ Jan. 1945, Krapovickas 1063 (III, SI); entre Fortín y Mojon de Fierro, 7 Jan. 1945, Ragonese y Cozzo 1198 (BABosq); PIRANE: 12 Nov. 1945, Morel 339 (IIL) and Casco-Cue, $15 \mathrm{Febr} .1946,284$ (IIL, S); CHACO: Villa Formosa, 19 Mar. 1885, Kurtz 1570 (CORD); 'hojas verde oscuro reluciente", Mever 98 (SI); Colonia Pastoril, 23 Nov. 1938, Moloko 2458 (BABosq); km. 522, 15 Jan. 1945, Ragonese \& Cozzc 2591 (BABosq) and 2601 (BABosq), 16 Jan. 1945, 2606 (BABosq) and 17 Jan. 1945 , Ragonese \& Cozzo 2588 (BABosq): Puesto Puente Nacional, 21 Jul. 1944. Rojas 11689 (III); RESISTENCIA: 28 Febr. 1908, Burco 18607 (G); Laguna Charale, 8 Jul. 1924, Castellanos s.n. (BA); vicinity of Barranqueras, 35-40 m. alt., 12. Nov, -15 Dec. 1913, Curran 20 (US), 55 (F, GH, NY, US), 380 (US) and Fortin Cardoso, June 1914, Curran 654 (F, LII); 10 Mar. 1916, Lillo 18187 (LIJ); Fortín Cardoso, i7 March 1947. Malvarez 1331 ('TII); entre Rio Araza y Tiel, $55 \mathrm{~m}$. alt., 16 May 1945, Meyer 9011 (GH, LIL); Barranqueras, $14 \mathrm{Nov} .1913$, Muniez, Acevedo \& Curran 20 (III), Resistencia, 15 Nov. 1913, 379 (BAB) and Fortin Cardoso, 15 Nov. 1913. Muniez, Acevedo \& Curran 380 (LIL); Colonia Colonia Benítez, $15 \mathrm{Mar}$ 1940, Muñoz 1310 (BABosq); Resistencia, 
28 Feb. 1908, Rojas 18 (CORD); Barranca Río Negro, 10 June 1944 , Rojas 11580 (As, GH, IIL) and Río Negro, 12 Aug. 1944, 11931 (AS, IIL); Colonia Benitez, Jan. 1928, Schulz 136 (BAB), Dec. 1929, 164 (BAF) and Dec. 1933, Schulz 844 (NY); RIO BERMEJO: Rio de Oro, k. 140, 30. Aug. 1944, Rnjas 12148 (AS, LII); TAPENAGA: Cote Lai, Dec. 1942, Meyer $472 \mathrm{~S}$ (III); MISIONES: Mar. 1888, Niederlein S.n. (BA); Itaimbe, 5 Jan. $\frac{1935}{193}$ Rodriguez 474 (BA); CAINGUAS: Puerto Rico, 29 Dec. 1947. Schwindt 218 (III); CANDETARIA: Cerro Corí, $200 \mathrm{~m}$. alt., 27 Nov. 1949, Bertoni 4686 (III); entre Loreto y Santa Ana, 29 Jan. 1933, Grüer s.n. (LP, NY);

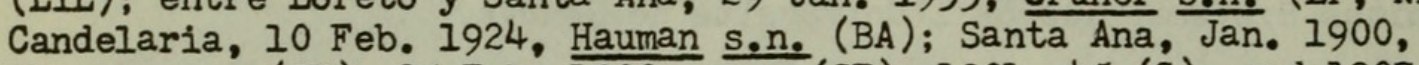
Ilamas s.n. (SI), $25 \mathrm{Feb}$. $1900, \mathrm{s,n_{0 }}$ (SI), 1901, 45 (G), and 1907,

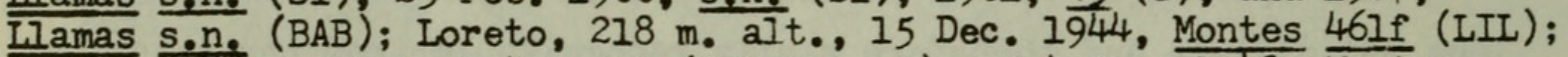
$218 \mathrm{~m}_{\bullet}$ alt., $15 \mathrm{Feb} .1945,559$ (GH, LII, S) and 4 Jan. 1943, Montes 54003 (BA); Santa Ana, 20 Sept. 1912, Rodriguez 635 (BA, BAF, LII, NY, SI); CAPITAL: Posadas, $150 \mathrm{~m}$. alt., 28 Dec. 1944, Bertoni 550 (III) and Zaiman, 28 Dec. 19'45, 21539 (LII); alrededores de Posadas, 6 Dec. 1947 , Cozzo II7M (BA); Posadas, 2 Dec. 1912, Curran 17 (LIL), 2 Dec. 1913, 417 (BAB) and 5-7 Dec. 1913, Curran 17 (US): Posadas, 26 Sept. 1900, Gerling $6801(\mathrm{BAB})$ and $6808(\mathrm{BAB}) ; \mathrm{Posadas}, 2 \mathrm{Jan}, 1911$, Lillo 10587 (GH, LII); Posadas, $25 \mathrm{Feb}$. 1944, Meyer 5824 (LIL), $16 \mathrm{Feb} .1944,6005$ (LII) and 20 Jan. 1947, Meyer 11337 (LIL); Posadas, 12 Jan. 1907, Spegazzini s.n. $(B A B)$ and 18 Jan. 1907, s.n. (BAB); SAN JAVIER: Aug. 1902, Burmeister 6807 (BAB); SAN IGNACIO: 1918, Denis 6 (BA); CORRIENTES: Capital: Corrientes, 26 Jan. 1944, Meyer 5900 (GH, IIL) and $24-28$ Jan. 1944 , 6635 (III); GENERAL PAZ: Ita Ibate, 11 Jan. 1946. Tbarrola 1058 (F, III, S); Ita Ibate, 22 Aug. 1922, Rojas 4334 (BAF) and Barranca Rio Paraná, 6 July 1944, Rojas 11540 (AS, III); SAN COSME: Paso de la Patria (Costa Toledo), 25 May 1945, Meyer 9003 (IIL); SANTO TOME: Feb. 1910, Venturi. s.n. (IIL); SANTA FE: GENERAL OBLIGATO: entre Rabon y Florencia, 10 Jan. 1937. Castellanos S.n. (BA); entre Rabon y Florencia, 10 Jan. 1937, Ragonese 2413 (IP) and 12 Feb. 1938, 3240 (LP).

\section{IIb. Section Macrocalyx, $\underset{\sim}{\text {. sect. }}$}

Fructus obconicus, endocarpio chartaceo; sepala fructum circumdantia quam $2 \underline{\mathrm{cm}}$. maiora.

Fruit globose-obconical, endocarp chartaceous; calyx segments over $2 \mathrm{~cm}$. long.

This section contains what has previously been considered two species, but what the present writer believes is a single, quite uniform species.

13. Astronium concinnum Schott in Spreng. Linn, Syst, Veg. (VI), 404. 1827.

Myracrodruon concinnum (Schott.) Engl. in Martius \& Eichl., Flora Brasil 12 1201.1876. 


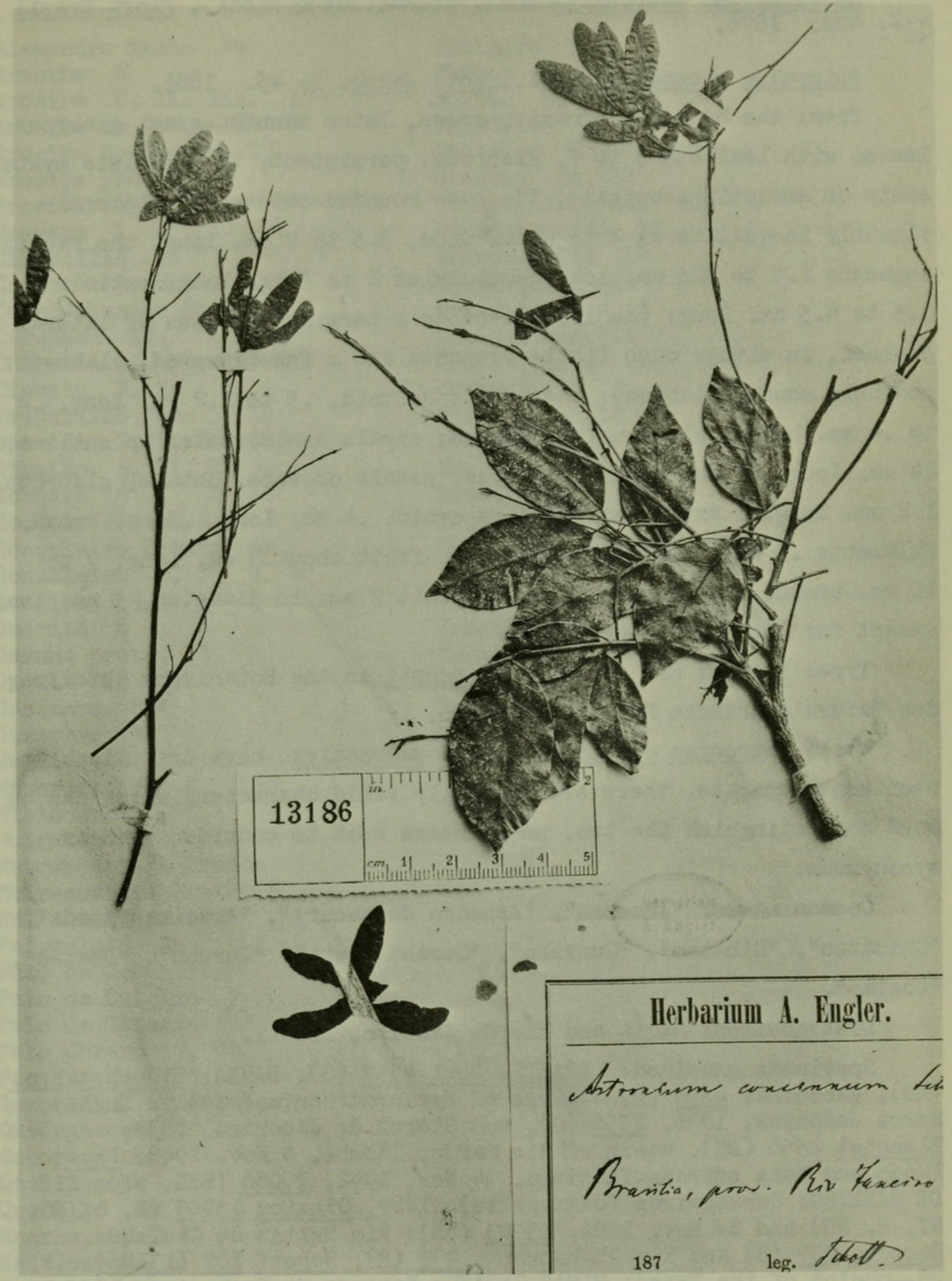

PLATE VI. Photograph of Astronium concinnum Schott in Sprenge1. From Schott 187 in the Berlin Herbarium. Note the very large fruits. (Photo courtesy of the Field Museum of Natural History, Chicago.) 
Myracrodmuon macrocalyx Engl. in Martius \& Eichl., Flora Brasil $12^{2}: 402 \cdot 1876$

Astronium macrocalyx Engl., Bot. Jahrb. 1: 45.1881.

Tree; the branches brownish-green, later tannish-gray, glabrous; leaves with leaflets 3 to 7 , glabrous, persistent, the leaflets ovate, acute or abruptly acuminate, the base rounded-obtuse, the lateral slightly inequalateral 2 to $4 \mathrm{~cm}$. wide, 3.5 to $7 \mathrm{~cm}$. long, the rachis segments 1.5 to $2.5 \mathrm{~cm}$. long, petiolules 2 to $5 \mathrm{~mm}$. long, petiole 2.5 to $4.5 \mathrm{~cm}$. long; the inflorescence a terminal thyrsus or lateral panicle, in either case little-branched and a few-flowered, glabrous; pedicels short, glabrous; the bracts deltoid, .5 to $1.2 \mathrm{~mm}$. long, .2 to $.4 \mathrm{~mm}$. broad, glabrous, caducuous; sepals semicircular in outline, $.4 \mathrm{~mm}$. long, $.5 \mathrm{~mm}$. broad, glabrous; petals obovate, obtuse, glabrous, $1.2 \mathrm{~mm}$. long, $1 \mathrm{~mm}$. broad; anthers ovoid, $.4 \mathrm{~mm}$. long, $.2 \mathrm{~mm}$. broad, filaments $.3 \mathrm{~mm}$. long; calyx lobes in fruit about $3 \mathrm{~cm}$. long, 7 to $10 \mathrm{~mm}$. broad, obtuse, the ovary in fruit ? mm. in diameter, $5 \mathrm{~mm}$. Iong except for the $3 \mathrm{~mm}$. long style.

Type: Brazil : Río de Janeiro, Schott in the Botanische Abteilung des Naturhistorische Museums von Wien.

While Astronium concinnum and A, macrocalyx have traditionally been kept separate, there are no really valid characters which can be used to distinguish the two, so it seems best to consider them as synonymous.

Common names: "Aroeira", "Aroeira do Mucury", "Aroeira rajada", "Chibatan", "Gibatão", "Guaribú", "Guraba preta", "Gurubú", "Ubatan", "Ubatão".

Distribution: Bahía and Río de Janeiro, Brazil.

Specimens examined: BRAZIL: Pohl 4557 (G); BAHIA: Blanchet S.n. (MG), Jacobina, 2556 (F, G--Type of Myracrodruon macrocalyx EngI.), Serra Jacobina, 1836,2556 ( $C$ ) , and Sierra de Jacobina, 1839. Blanchet 2556 (NY); basin of Rio Pardo, Itombe, 4 Nov. 1942 , Froés $\overline{12655}$ and Mata estrada Itatinga, 24 Nov. 1942, 20080 (BEI, NY); RIO DE JANEIRO: Garangairas (Cantagallo), 1887, Giaziou 15903 (F, G, MG, $N Y, R, R B$ ) and 24 Nov, 1886, 15903 (US); Rio Sertas de Cacimbos, Sampaio 937 (R) and Rio Itabaprana,. 239 (R); Schott 187 (13186) (F, US--photos of the Type); MINAS GERAES: Fazenda da Cachoeira, 18 July 1935, Mel10 1654 (R). 
INDEX OF COMMON NAMES

Alemandro Macho $6 a$ Arantha 6

Aroeira 6, 11, 11a, 13

Aroeira de Campo 11

Aroeira do Mucury 13

Aroeira preta 11

Aroeira rajada 13

Bauwana 1

Ciruelillo 8b

Copaiva 7, 8b

Cuchi-blanco 6a

Curupach 12

Chibatan 5, 11, 13

Diomate 7, 7a

Frijolillo 8b

Gateado 7, 8, 8b

Gibatão 5, 11, 13

Gonçalo 6

Gonçalo Alves 6, ?

Gonçeleiro Branco $6 a$

Gonzaleiro 6, ?

Guaribu 13

Guarita 6

Gurabą preta 13

Gurubu 13

Gusanero 8b

Guzanero 7

Jejuira 5

Miracoatiara 2

Misionero 2

Muiracoatiara $2 a$

Muiracoatiara Branca 5

Muiracotiara Preta 5

Muiraquatiara 2

Palemulato ?

$\mathrm{Palo}$ de Cera?

Palo de Culebra?

Palo de Gateado ?

Palo Obrero ?, 8b

Pao Ferro 12

Quebracho 6, 6a, 7, 7a

Quebrahacha 7

Quebra Hacha $7 a$

Quebrahacho 6

Quesilllo 8b

Ronrón 7, 8b

Sete-carcas 6

Sotocolo 11
Tibigare ?

Ubatan 5, 11, 13

Ubatão $5,11,13$

Urindeuva 11

Urundahy 12

Urunday $6 a, 12$

Urunday colorado 12

Urunday-pardo 12

Urunday-pița 12

Urundejh-mí 12

Urundeih-pará 5

Urundei-mi $11 a$

Urundej-paráa $6 a$

Urunde j-ita 5

Urundel 5, 12

Urundeuva 11

Urundey $5,11,12$

Urundey-mi 5,11

Urundey-pará 5

Urundey-pichai 12

Yoke 4

Yomate ?

Zongalia 8

Zongalica 8

Zarro ?

Zorro ? 
Aerojado Lisbea, M. 2459 (11)

Aguilar, Ignacio 634 (b)

Aguilar H., Mercedes 327 (7)

Allemão, Francisca s.n. (3); s.n. (6); s.n. (11)

Allemão, Fr. \& M. de Cysneiros 324 (6)

Balansa, B. 2526, 3188 (12); 2528, 3265 (11a)

Bertoni, M. L. $440,4686,21539$ (12)

Blanchet, J. 2765 (6); 3418 (10); s.n., 2556 (13)

Bonpland, A. 497 (12)

Brade, A. C. 11068 (6a)

Brenes, A. M. s.n., 43 (8a)

Britton, N. L. \& T. E. Hazen 1706 (4)

Broadway, W. E. $557 ?$ (4)

Burco, M. 18607 (12)

Burmeister, Carlos 6807 (12)

Calderón, Salvador 2153, 2216

Campos Porto, P. 10519 (5)

Capucho, $369,372,380,385$

Carlson, Margery C. 664 (7)

Carmelich, J. N. F. \& Florentine Rial Alberti 366 (II)

Castellanos, Alberto s.n., s.n. (12)

Castiglioni, J. A. \& J. C. Tinto 2968, 2971 (II)

Claps de Willink, Lila 299 (II)

Claussen, M. s.n., 473 (6); s.n., 473 (11)

Conzatti, Cassiano, B. P. Reko \& Emil Makrinius 3051

Cozzo, D. I17M (12)

Curran, H. M. 354 (7); 188 (8b); 17, 20, 55, 380, 417, 654 (12) Curran, H. M. \& M. Haman 457,490 (1)

Daguerre, Juan B. s.n. (12)

Denis, León 6 (12)

Devoto, Franco Enrique \& F. Rial Alberti s.n. (1l)

Ducke, Adolfo s.n., 8, 852, 11390, 18161, 18162, 24814, 24816 (2); s.n., s.n., s.n., s.n. (5); s.n. (6); s.n., s.n., s.n.,

Ducke, Adolfo \& P. LeCointe 15756 (2)

Dugand, Armando 1041 (6a); 34,782, 1059 (7a); 918, 977, 978 (7b)

Dugand, Armando \& Roberto Jaramilio 3422 (7a)

Dugand, Armando \& G. Juan Mina 939 (7b)

Hermano Elias 1305 (7); 10541 (7a)

Espina, 61 (7a)

Fiebrig, Karl 256 (5); s.n., 1271, 2198 (11); 1271 (11a)

Friegs, Robert E. 456, i409 (i工)

Froes, Ricardo de Lemos 26417 (2); 12655, 20080 (13)

Gamon, John A. 19 (8)

Gardner, M. 1535 (6); 2520 (10)

Gaumer, George F. 582, 584, 24170, 24171 (7); 24171 (8b)

Gaumer, G. F. \& sons 23772 (7) 
Gerling, G. F. 6801,6809 (12)

Glaziou, A. F. M. 19011 (3); 9390 (5); s.n., 10490 (6); 12542 , 12942 (6a); 12543, 12943, 20869 (11); 15903 (13)

Grüner, G., s.n. (12)

Guevara, Amortegui, B. 380 (7)

Guillemón, 469 (5)

Gutierrez V., Gabriel 18, 34 (7b)

Hassler, Emil 3142, 6224 (5a); 867, 1898, 1898a, 3142, 7151, $11898,11898 a$ (6a); 1890, 1890a, 7215, 11890, $11890 a$ (11); $7216,12202,12202 a$ (11a)

Haught, Oscar 4032 (6a)

Hauman Merck, Lucien s.n., s.n. (11); s.n. (12)

Herringer, E. P. 263 (3)

Hoehne, F. C., \& A. Gehrt s.n. (5)

Hottle, W. D. $22(8 \mathrm{~b})$

Tbarrola, Tito 1058 (12)

Jọrdão, Armando 301 (II)

Jörgensen Hansen, Pedro s.n., 3902 (11); 2056 (12)

Kug, G. 3254 (7)

Krapovickas, Antonio 1063 (12)

Krukoff, B. A. 5398 (5); 10259

Kuhleman, J. G. S.n., 6023 (3)

Kuhlmann, Moyses 576 (5)

Kuntze, Otto s.n. (6); s.n., s.n. (11)

Kurtz, F. 1570 (12)

Lilllo, Miguel 5277, 5279, 18087 (II); s.n., 10789, 10842 (11a); 10587,18187 (12)

Lisboa, Arrojado s.n. (10)

Iorentz, Pablo Gunther \& Georg Hans Emmo Wolfgang Hieronymus s.n., s.n., 394, 418 (11)

von Luetzelburg, $\mathrm{Ph}$. 12001 (II)

Lundell, Cyrus L. 6339 (8); 2881, 3095 (8a); 6339 (8b)

Llamas, A. s.n., s.n., s.n., 45, 419 (12)

Macedo, Amaro 439 (6); 457 (i1)

Malme, Gust. O. A:n 1918a, 1918b (6); 1918 (6a)

Malvarez, R. 1331 (12)

Matuda, Bizi 16451, 16518 (8b)

Mell, C. D. s.n., 6 (8)

Mello Barreto, F. L. 10230 (6); 1543 (6a); 1654 (13)

Mendes Magalhã́es, Geraldo 941 (10)

Meyer, Teodoro 4886, 9871, 12663 (11); 98, 4729, 5824, 5900, 6005, $6635,9003,9011,11337$ (12)

Moloko, Juan 2458 (12)

Montes, J. E. 461f, 559, 54003 (12)

Morel, Ismael 339, 984 (12)

Morton, C. V. \& Emil Makrinius 2436, 2601 (8)

Muniez, Abel A., R. Acevedo \& H. M. Curran 20,379, 380 (12)

Muñoz, E. Y. 1310 (12)

Murça Pires, João \& George A. Black 1573a (10) 
Mutis, Celeștino 4431 (7)

Nestor, José s.n. (II)

Niederlein, Gustavo s.n.

Occhioni, I0519 (5)

Osten, Cornelio 9009 (6a)

Osten, Cornelio \& Teodoro Rojas 9008, 9009, 9010 (5)

Pastrana, Julio 9136 (II)

Pavetti Morín, Caludio V. \& Teodoro Jojas 1064la (5); 10931, $10931 a$ (12)

Pérez Arbelaez, Enrique s.n. (6a)

Pflanz, K. 4085 (11)

Pickel, B. 3250 (6)

Pittier, Henri 8679 (6); 3730, 11435 (7); 6997, 7650, 11435 (8b)

Pohl, J. E. 4557 (13)

Purpus, C. A. 8761, 16429 (9)

Ragonese, Antonio Enrique 318 (11); 2413, 3240 (12)

Ragonese, A. E. \& Domingo Cozzo 1198, 2588, 2591, 2601, 2606 (12)

Reales, Armando 127 (12)

Record, Samuel J. 63 (7a)

Reko, Blas Pablo 4192 ( $8 \mathrm{~b}$ )

Rodriguez, A. P. 474 (12)

Rodríguez, D. 133 (11)

Rodriguez, F. M. 635 (12)

Rojas Acosta, N. 18 (12)

Rojas, Teodoro 6182a, $10641 \mathrm{a}$ (f); 7012 (6a); 7712 (11); 3460, $3460 \mathrm{a}, 4334,10931,10931 \mathrm{a}, 11540,11580,11689,11931$, 12148,12642 (12)

Romero Castañeda, R. 698 (7b); s.n. (8b)

de Sampaio, A. J. 937,939 (13)

Schott, A. C. V. 187 (13186) (13)

Schreiter, Rodolfo 28, 5018, 5028, 11380, 11381, 11382 (11); 3390 , 5028, 11382 (11a)

Schultes, Richard Evans \& Blas Pablo Reko 769 (7)

Schulz, Augusto Gustavo, $136,164,844$ (12)

Schulz, Carlos L. \& Ramón Zenón Varela 5386, 5388 (11)

Schulz, F. 8170 (II)

Schwindt, Elena 518 (12)

Shattuck, Otis 632,866 (8b)

Smith, Albert C. 3i26, 3466 (1)

Smith, Herbert H. 823, 908,910

von Sneidern, Kjel 1262 (7)

Spegazini, Carlos 1490 (11); s.n., s.n. (12)

Standley, Paul Carpenter 55063 ( 7 ); 23947, 26183, 28942, 29377, $29951,30550,53883_{3} 53984,54065,54680,55097,74308(8 \mathrm{~b})$

Standley, P. C. \& Jaime Chacoon P. 576 ? (8b)

Standley, P. C. \& H. H. Londelie 7287 (8b)

Standley, P. C. \& Hilas Padilla V. 2865, 3218 (8b)

Standley, P. C, \& Juvenal Valerio 44916 (8b)

Steinbach, Jose 2717,6693 (6); 1570,3532 (6a); 7471, 7921 (11) 
Stern, W. L. \& K. L. Chambers 129 (8b)

Stevenson, N. S. 102, 107 (7)

Steyermark, Julian A. 62871 (2); s.n., 32068, 38094, 38145, 42144,

Tatto, Lino 18 (5) $45201,45306,46117,47338,5116 ?$ ( $8 \mathrm{~b})$

Triana, J. s.n., 25294 (7a)

Turner, Marshall 138 (7); 145 (7a)

Ule, E. 7958, 7960 (1); 9551 (5); 7283 (11)

Venturi, Santiago 316, 5033, 5043, 5417, 9698, 10609, 10632 (11);

$$
\text { s.n. (12) }
$$

Villa, I. s.n. (12)

Werdermann, E. 2488 (6a)

Whitford, H. N. is J. Pinzon 15 (8b)

Whitford, H. N. \& L. R. Stadtmiller 20 (8b)

Williams, Llewelyn 11655 (2); 8753, 9517 (8b)

Zehntner, $\quad 369,407$ (6); 319 (11)

\section{INDEX OF SCIENTIFIC NAMES}

Astroniur balansae Engl. 12

Astronium Candolei Engl. Ila

Astronium concinnum Schott in Sprengel 13

Astronium conzattii Blake 8

Astronium conzattii var. lundellii Barkl. 8a

Astronium conzattii var. standleyi Barkl. 8b

Astronium fraxinifolium Schott in Sprengel 6

Astronium fraxinifolium Standl. 9

Astronium fraxinifolium f. glaberrimum Matt. $6 a$

Astronium fraxinifolium var. glabrum Engler in DC. $6 a$

Astronium fraxinifolium f. mollissimum Matt.

Astronium fraxinifolium f. pilosum Matt. 6

Astronium fraxinifolium f. subglabrum Matt. $6 a$

Astronium gardneri Matt. 10

Astronium glaziovii Matt. 3

Astronium gracile Engl. 5

Astronium gracile f. acuminatum Chodat \& Hassl. $5 a$

Astronium gracile var. acuminatum (Chodat \& Hassler) Barkl. $5 a$

Astronium graveolens Jacq. ?

Astronium graveolens var. brasiliensis Engler in Mart. \& Eichl. 5

Astronium graveolens var. dugandii Barkl. $7 \mathrm{~b}$

Astronium graveolens var. inodorum Triana \& Planchon $7 a$

Astronium graveolens var. Planchonianum Engler in Mart. \& Eichl. 7a

Astronium juglandifolium Griseb. 11

Astronium lecointei Ducke 2

Astronium Le Cointei f. tomentosum Matt. 2a

Astronium lecointei var. tomentosum (Matt.) Barkl. 2a

Astronium macrocalyx Engl. 13

Astronium mirandae Barkl. 9

Astronium obliquum Griseb. 4

Astronium ulei Mattick 1 
Astronium urundeuva (Fr. All.) Engl. I

Astronium urundeuva var. candollei (Engl.) Hassl. ex Mattick lla Astronium zongolica Reko 8

Myracrodruon concinnum (Schott.) Engl. 13

Myracrodruon macrocalyx Engl. 13

Myracrodruon Urundeuva M. Fr. Allemão in M. Fr. Allemão \& F. Fr. AII emão 11 


\section{$2 \mathrm{BHL}$ Biodiversity Heritage Library}

Barkley, Fred A. 1968. "Anacardiaceae: Rhoideae: Astronium." Phytologia 16, 107-152. https://doi.org/10.5962/bhl.part.21077.

View This Item Online: https://www.biodiversitylibrary.org/item/46709

DOI: https://doi.org/10.5962/bhl.part.21077

Permalink: https://www.biodiversitylibrary.org/partpdf/21077

\section{Holding Institution}

New York Botanical Garden, LuEsther T. Mertz Library

\section{Sponsored by}

The LuEsther T Mertz Library, the New York Botanical Garden

\section{Copyright \& Reuse}

Copyright Status: In copyright. Digitized with the permission of the rights holder.

Rights Holder: Phytologia

License: http://creativecommons.org/licenses/by-nc-sa/3.0/

Rights: https://biodiversitylibrary.org/permissions

This document was created from content at the Biodiversity Heritage Library, the world's largest open access digital library for biodiversity literature and archives. Visit BHL at https://www.biodiversitylibrary.org. 